\title{
Fukushima 1st NPPs Accidents and Disaster Caused by the Pacific Coast Tsunami of Tohoku Earthquake
}

\author{
-Lessons from Evaluation of the Fukushima 1st NPPs
} Accidents-

\author{
Hokkaido University, Tadashi Narabayashi and Kenichiro Sugiyama
}

The Fukushima Daiichi Nuclear Power Stations (NPSs) Accidents were an unprecedented severe accident that were triggered by the 2011 Off the Pacific Coast huge earthquake of magnitude 9.0 and a great tsunami, which occurred and progressed simultaneously in multiple units. This situation was reported in the mass media one by one, and many people experienced the devastation of the nuclear power station accident and the fear of radiation contamination. From the viewpoint of defense in depth, people involved in nuclear energy should conduct comprehensive inspection of the safety facilities available in nuclear power stations with a firm resolution to not cause any trouble to the residents regardless of the disaster type. The authors hope that the nuclear energy of Japan will recover based on these lessons.

\section{Introduction}

The 2011 Off the Pacific Coast of Tohoku Earthquake occurred at 14:46:18 on March 11, 2011, with epicenter at Japan's Sanriku off the Pacific Coast. It was a massive earthquake with a magnitude of 9.0, which generated a large tsunami on the Pacific Coast from Hokkaido to Chiba Prefecture, causing devastating damages, especially in northeastern area of Japan. This earthquake was named the 2011 Off the Pacific Coast of Tohoku Earthquake. Several thermal and nuclear power stations built on this coast were damaged and their operations tripped. Especially in Units 1-4 of Fukushima Daiichi Nuclear Power Station (NPS), which are operated by Tokyo Electric Power Company (TEPCO), both the external and emergency power units were lost, and after losing the core cooling function, the core melt down. Additionally, water supply to the spent fuel pools was stopped within a few days. As a result of core damage, radioactive materials were released into the atmosphere, which caused radioactive contamination not only on the surrounding area but also the water reservoirs even in the metropolitan area.

It was a serious accident that should not have occurred at a commercial nuclear power station. In the midst of unbearable situations reported in the media, such as the people whose

DOI : 10.15669/fukushimainsights.Vol.1.3

(C) 2021 Atomic Energy Society of Japan. All rights reserved.

Originally published in Journal of the Atomic Energy Society of Japan (ISSN 1882-2606), Vol. 53, No. 6, p. 387-400 (2011)

in Japanese. (Japanese version accepted: May 6, 2011) 
suffering from the tsunami damage was worsened by the forced emergency evacuation; disposal of contaminated vegetables, milk, and fishery; the slaughters of surviving livestock; and the damage caused by the rumors spread by media articles, the authors of this paper, who have been studying the nuclear safety and severe accident, followed the transition of the accident and conducted data analysis while hoping for an early convergence of the accident. In future, it is necessary to conduct detailed investigation of the accident and the analysis of its cause, and urgently take safety measures to avoid repeating the same situation. This commentary summarizes the research and analysis results obtained so far.

\section{Outline of the Fukushima Nuclear Power Station Accident}

\section{Outline of the Earthquake Disaster}

During this disaster, an earthquake of magnitude 9.0 triggered a large tsunami along the Pacific Coast, which stopped the operation of many large thermal and nuclear power stations along the Pacific Coast of northeastern Japan, except some thermal power plant and Kashiwazaki-Kariwa NPS of Japan sea side (Figure 1). This led to a loss in the external power over a wide area ${ }^{1,2)}$.

Since these nuclear power stations on the coast underwent seismic reinforcement work, their class A earthquake-proof reactor building (R/B) or the components inside the reactors were sound after even the severe earthquake. After losing the external power supplies, the scram and emergency diesel generator (EDG) were started immediately, followed by the emergency core cooling system (ECCS). However, the tsunami that hit the Pacific Coast about one hour later led to a serious situation. Especially at the Fukushima Daiichi Nuclear Power Station, which is operated by TEPCO, the loss in all the external and emergency power sources, i.e., station blackout, and the loss of cooling and heat removal of fuels in the core and water supply of spent fuel storage pool caused the core damage, resulting in the radioactive materials being released into the atmosphere and causing severe impacts of radioactive contamination on the surrounding area $\mathrm{a}^{3,4)}$.

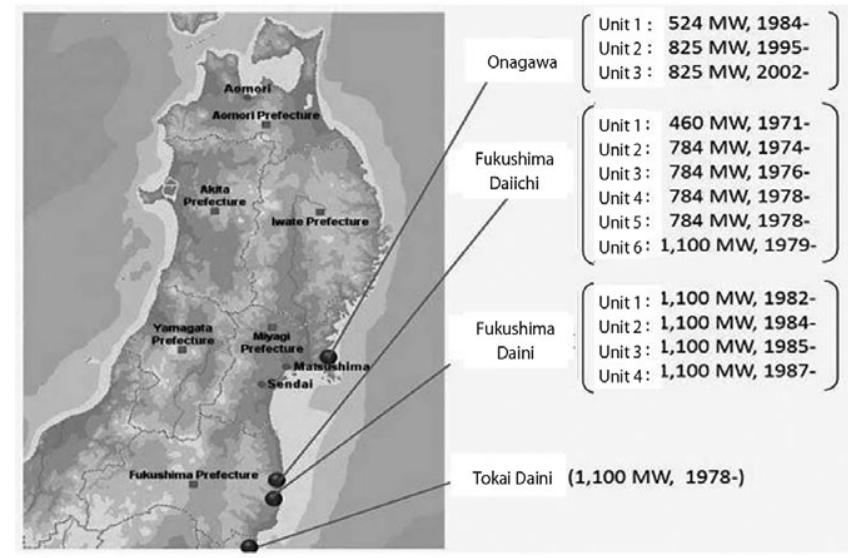

Figure 1 Nuclear power stations affected by the Great East Tohoku earthquake ${ }^{1)}$ 


\section{Impacts of the Earthquake and Tsunami on Fukushima Daiichi Nuclear Power Station}

The impact of the tsunami, which was a main cause of this accident, should be explained. The assumed maximum height of the tsunami (Japan Society of Civil Engineers, revised in 2002), was $5.7 \mathrm{~m}$ above the standard sea level, and the construction for the tsunami countermeasures had already been completed. However, the height of tsunami at this time was 14 $15 \mathrm{~m}$ above the standard sea level, hitting most of the R/B area, and the turbine building (T/B) was flooded with 4-5 $\mathrm{m}$ water. Therefore, some underground trench with an opening on the ground or the large component delivery entrance of the T/B was also partially damaged and became the route for seawater flowing into the R/B. It was possible to prevent the seawater flowing directly into R/B to some extent owing to its airtight structure; however, an onsite investigation of underground corridor between $\mathrm{R} / \mathrm{B}$ and $\mathrm{T} / \mathrm{B}$ needs to be conducted to ascertain this. There were also infiltration of seawater into a radioactive waste building ( $\mathrm{Rad}$ ) on the south side of Unit 1. According to Figure 2 (a), one of the two heavy oil tanks installed near the water intake of Unit 1 was swept away by the buoyancy of tsunami, whereas the other was carried to the road on the north side of Unit 1. The earthquake-proof class A equipments, such as the condensed water storage tank or the diesel fuel tank, were used for the EDG. On

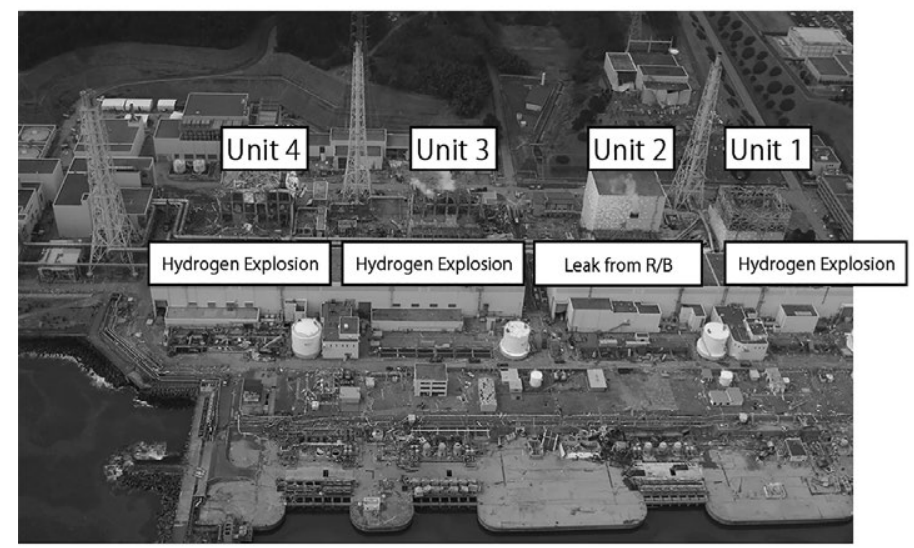

(a) Panoramic view of Fukushima Daiichi Nuclear Power Station (After hydrogen explosion) (Photograph by Air Photo Service)

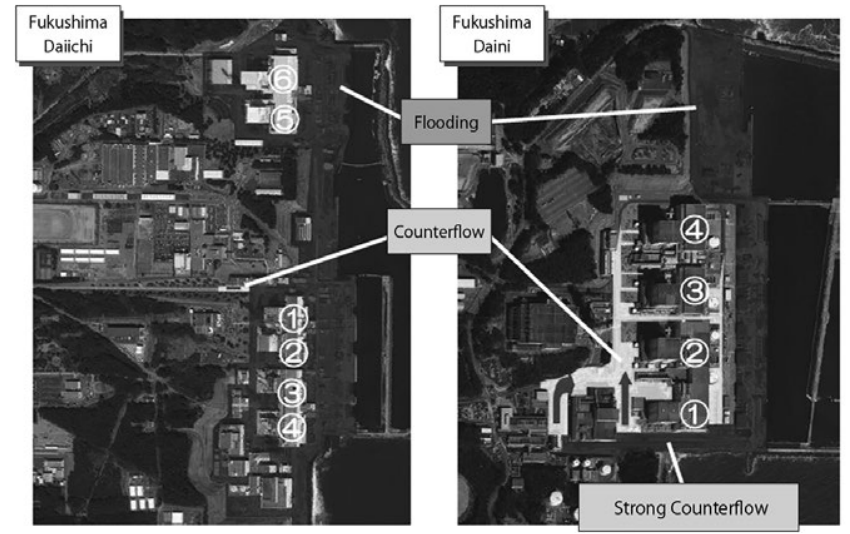

(b) Flooding and retroactive flow area after the tsunami (Fukushima Daiichi, Fukushima Daini) ${ }^{1)}$

Figure 2 Damage caused by the tsunami at Fukushima Daiichi and Daini Power Stations 
the other hand, extensive damage was caused in the seawater pump to supply cooling water for EDG and ECCS pump motors via heat exchanger. For instance, the motor of the seawater pumps that were under periodic inspection were swept away as far as near the seawater pump for Unit 2, as shown in Figure 2 (a).

Figure 2 (b) shows a comparison of the areas in Fukushima Daiichi and Daini Power Stations where flooding or retroactive flow was observed after the tsunami. The flooded area of Daiichi was larger, and as shown in Figure 3, it experienced station blackout caused by the loss of external power supplies and the unavailability of the EDG due to seawater infiltration.

Although the condensed water storage tank or the excess water of the waste processing tank was considered as the supply source of freshwater, most of the freshwater was injected into the reactor core. Meanwhile, there is 2.84 million tons of water in Sakashita Dam ${ }^{5}$, as shown in Figure 4, which was constructed during the construction of Daiichi Power Station to be used as a water source in the power station. Since there was a fresh water supply pipe from the dam to the sedimentation tank inside the power station premises, using this water was considered to be the most effective. However, the piping was damaged by the earthquake and repaired by the Self Defense Force. This water from the dam became usable only after more than 10 days since the start of seawater injection. During this time, securing freshwater was constantly an important issue; for example, the barges of the U.S. Army filled with freshwater came forward to provide water as help measures.

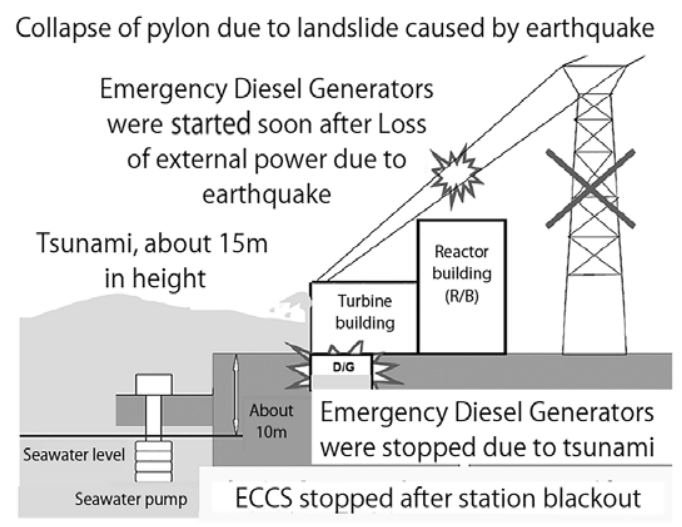

Figure 3 Station blackout caused by earthquake and tsunami ${ }^{1)}$

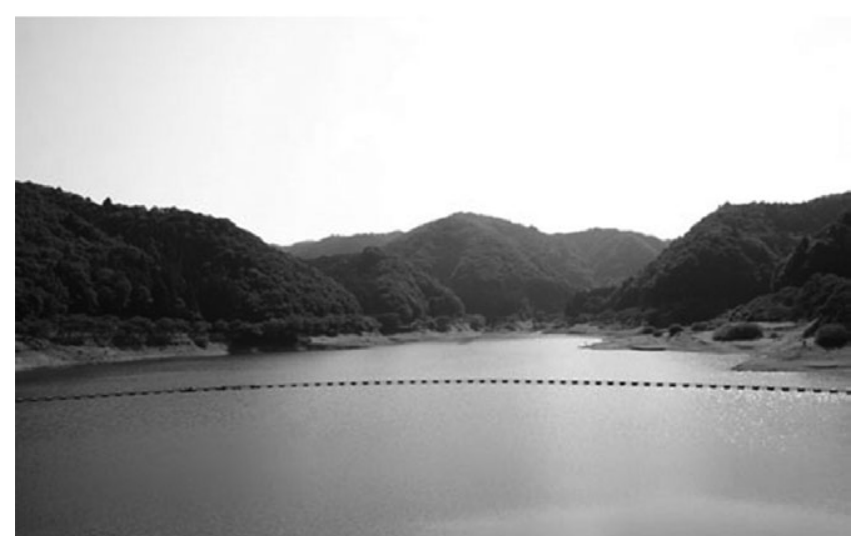

Figure 4 Sakashita Dam (Capacity 2.84 million ton) ${ }^{5)}$ 


\section{Safety System and Building Layout of Fukushima Daiichi Nuclear Power Station}

Figure 5 shows the system configuration of ECCS of BWR/4, which consists of a core spray (CS) and two low-pressure core injection (LPCI) systems. Each system is connected to its own EDG, which starts automatically when the external power supplies are lost. Moreover, it is equipped with a high-pressure core injection (HPCI) system driven by a steam turbine and reactor core isolation cooling (RCIC) system (nonsafety system). Unit 1 is BWR/3 and equipped with a passive isolation condenser (IC) instead of RCIC. It condenses the steam from the nuclear reactor and returns condensed water to the reactor core. Approximately 10 min after the IC starts, the steam generated from the secondary side of the pool is blown from the exhaust pipe of the R/B wall. When the HPCI or RCIC becomes unavailable, the main steam safety relief valve (SRV) is forced open; the main steam in reactor pressure vessel (RPV) is released into a doughnut-shaped suppression chamber, called torus (Figure 6), to reduce the pressure in the RPV, and water is injected using the LPCI. Besides the suppression chamber (S/C), the primary containment vessel (PCV) comprises flask-shaped drywell, S/C, and vent pipes that connect them. Headers are connected to the vent pipes and are attached to

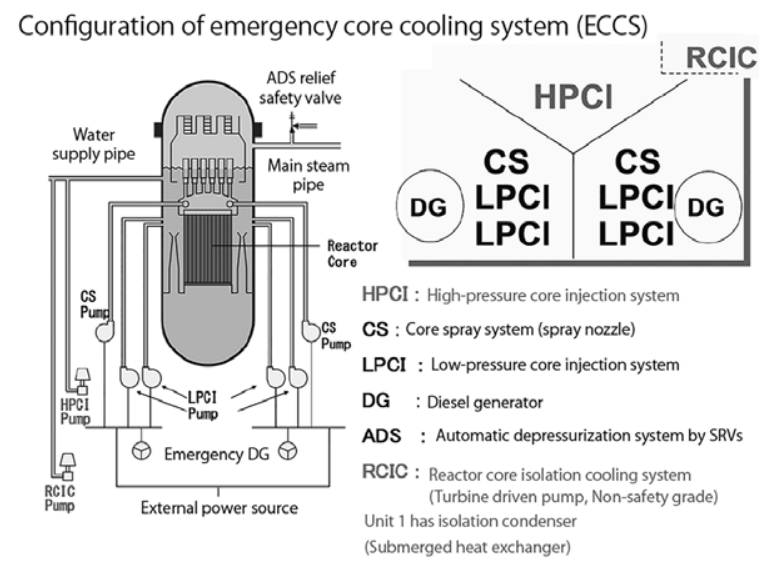

Figure 5 System configurations of ECCS of BWR/4 ${ }^{6)}$

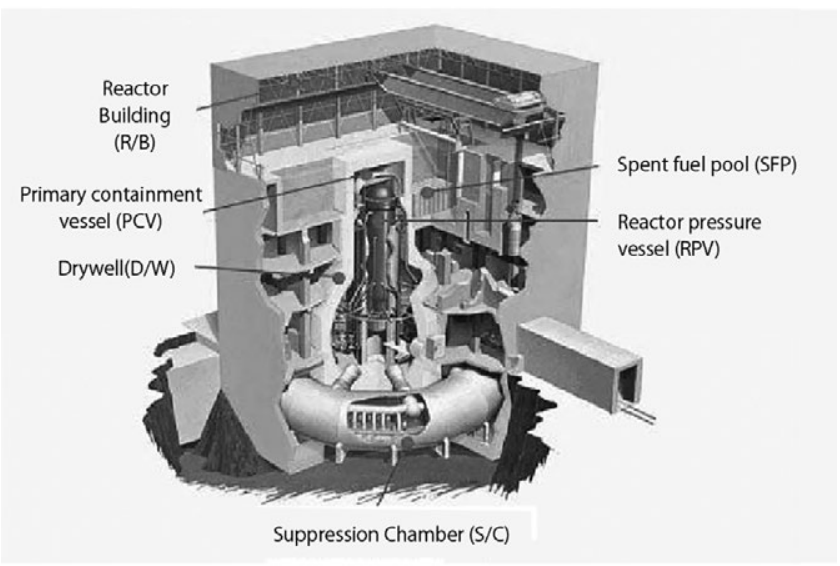

Figure 6 Mark-I Type PCV ${ }^{1)}$ 
many downcomer pipes. The downcomer pipes are submerged in the suppression pool (S/P) water and used to condense the drywell steam. Iodine and cesium contained in the steam are also filtered by this pool water.

Figure 7 shows the layout of the R/B of Unit 3 of Fukushima Daiichi NPS. It is crucial to remove the decay heat of core. Therefore, the residual heat removal (RHR) system was installed in the triangular corner of the four corners of the torus room on the first basement floor of $\mathrm{R} / \mathrm{B}^{7,8)}$. The decay heat is removed using RHR and seawater cooling systems into the sea water as an ultimate heat sink.

Figure 8 shows the bird's eye view of the overall layout of Unit 3 including the turbine building ${ }^{9)}$. The EDG is located on the first basement floor of the T/B. The main control room is located on the top floor of the control building next to R/B. The large component delivery gate on the first floor is used for hanging down fuels in a cask from the operating floor on top of R/B and loading them on trailers. The first basement floor is located-2.0 $\mathrm{m}$ above the standard sea level, the grand level of the first floor is at $10.2 \mathrm{~m}$, and the top of R/B is at $55.7 \mathrm{~m}$. Figure 9 shows the components layout inside the R/B of Unit $3{ }^{10)}$. The RPV is installed on a cylindrical plinth, called the pedestal, which extends over the reinforced concrete that covers the bottom of the drywell.

While exchanging the fuel in the reactor, a shield plug at the center of the operation floor is removed and PCV head flange is opened with an overhead traveling crane. The reactor,

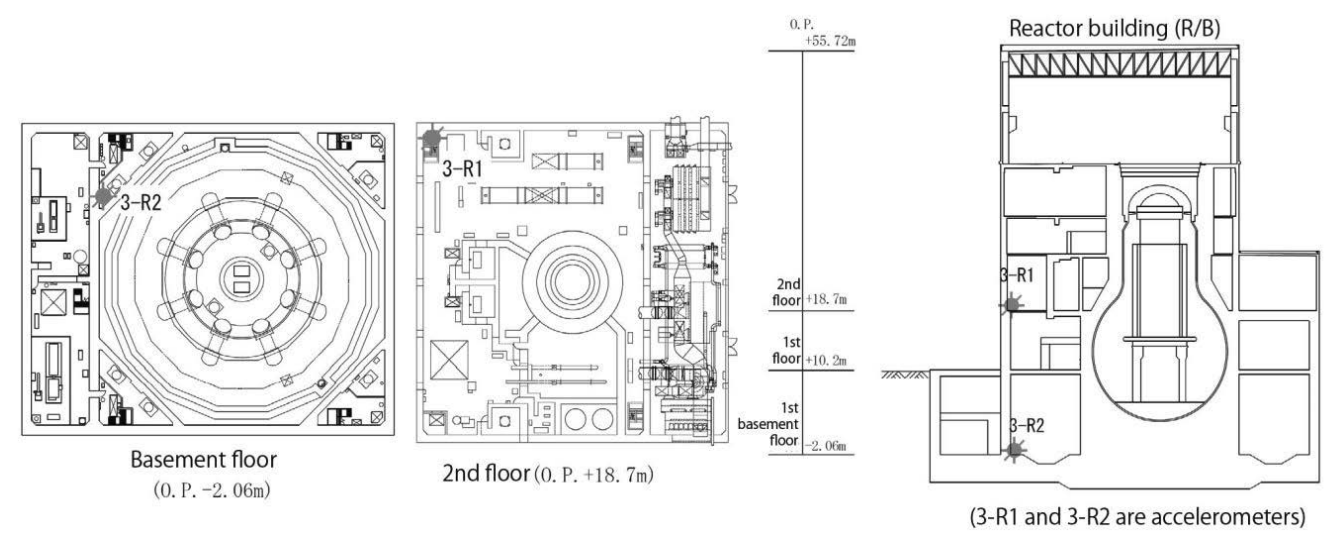

Figure 7 Layout of the R/B of Unit 3 of Fukushima Daiichi NPS ${ }^{7,8)}$

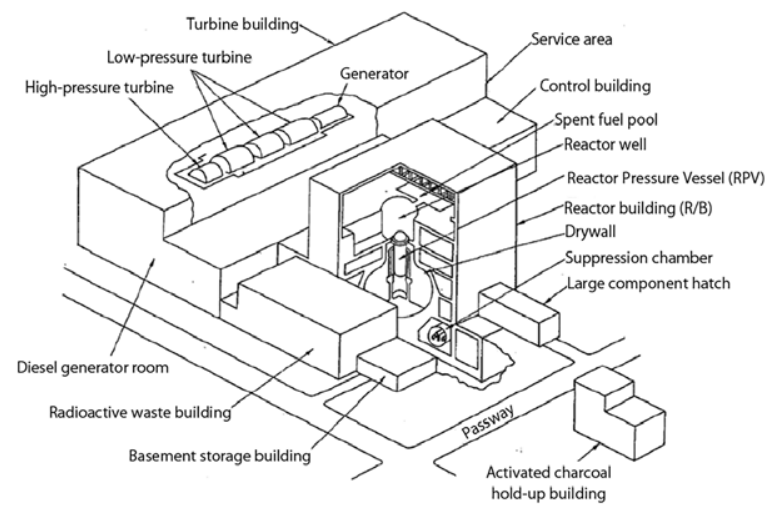

Figure 8 Bird's eye view of the overall layout of Unit 3 of Fukushima Daiichi NPS ${ }^{9)}$ 


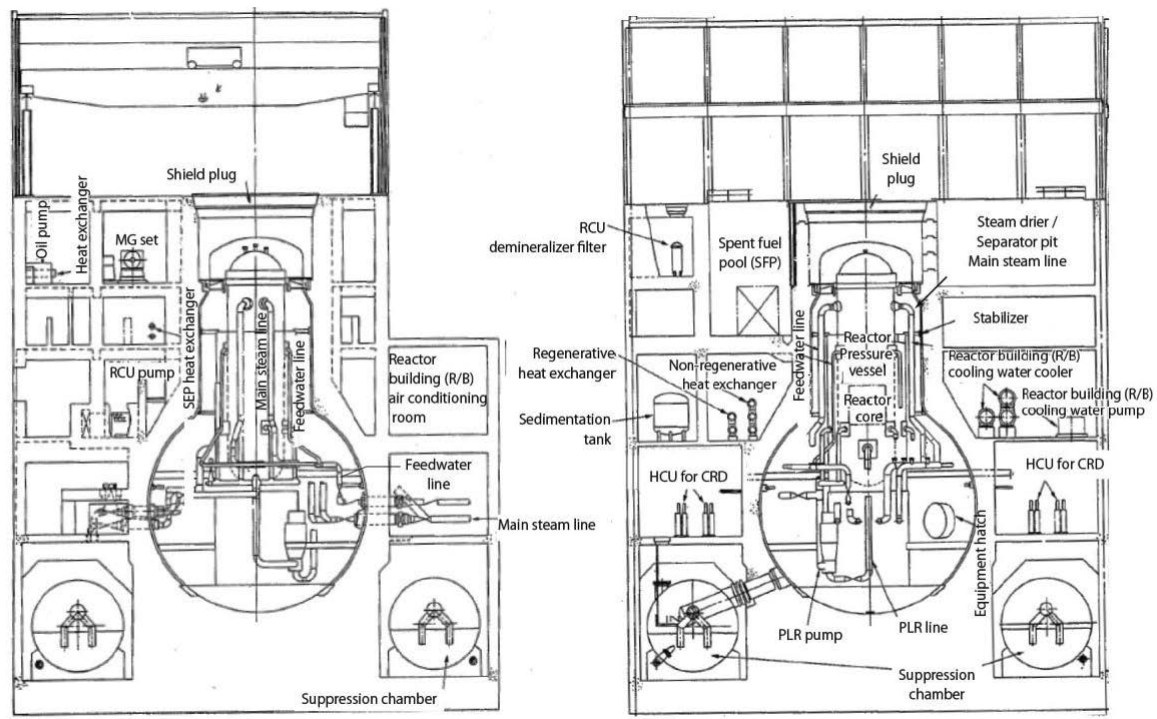

Figure 9 Component layout inside the R/B of Unit $3^{10)}$

which is well above the RPV, is filled with water and is connected with spent fuel pool. Then, RPV head flange is opened and the fuels in the core were exchanged. The spent fuel pool depth is $11 \mathrm{~m}$ and is stored in the lattice partition rack. The rack is attached to the pool bottom using anchor bolts. For natural convection, a hole is opened on the bottom of each fuel position (partition). Considering the lower tie-plate of the fuel, the active part of the fuel is about $50 \mathrm{~cm}$ from the pool bottom and about $7 \mathrm{~m}$ from the fuel top to the water surface (water shield for radiation protection). Without the volume of the fuels, the water quantity is about $1200 \mathrm{~m}^{3}$ in the case of Unit 4.

\section{Time Transition of the Fukushima Daiichi Nuclear Power Station Accident}

The time transition of the accident at Units 1-4 were as follows.

\section{(1) Unit 1}

This unit comprises one turbine-driven HPCI, two low-pressure CS as ECCS, and two ICs for RCIC, equipped in BWR/3. As shown in Figure 10 (b), soon after the scram by the earthquake, two EDGs were started by a loss in the external power and HPCI was also started. The decay heat removal and depressurization in RPV were conducted using two ICs that started automatically at $+7.1 \mathrm{MPa}$. Every cooling system was under good operation before the attack of tsunami. Unfortunately, cooling rate exceeded $55^{\circ} \mathrm{C} / \mathrm{h}\left(100^{\circ} \mathrm{F} / \mathrm{h}\right)$, and two ICs were stopped manually about $19 \mathrm{~min}$ after scram by an operator to meet the safety guide rule. Then, the operator adjusted the pressure near $7 \mathrm{MPa}$ by opening and closing the IC exit valve. When the tsunami came, the IC exit valve was closed, and the Unit 1 lost its entire cooling system.

The RPV pressure was kept as 7 MPa by SRV's safety mode, and steam was exhausted into S/P. Under such condition, water level should be decreased but the reactor water level (ם) increased at about 24:00 on March 11, as shown in Figure 11. This means that the temperature in PCV exceeded more than $300^{\circ} \mathrm{C}$ by core damage and water in a reference leg of water level measurement system decreased by vaporization. At the same time, PCV pressure increased and reached $750 \mathrm{kPa}$, near $2 \mathrm{Pd}$ (2 times the design pressure of $\mathrm{PCV})$ at 3:00 on March 


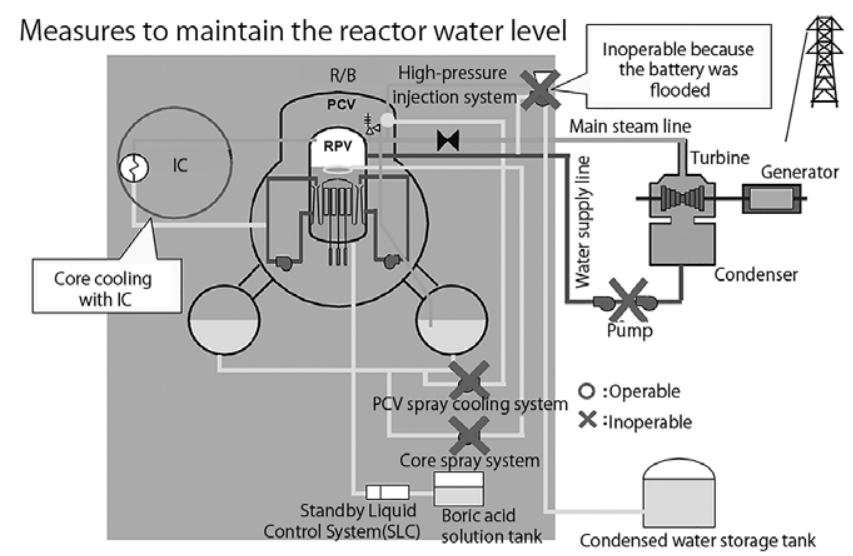

(a) Core cooling by IC during the station blackout immediately after the tsunami

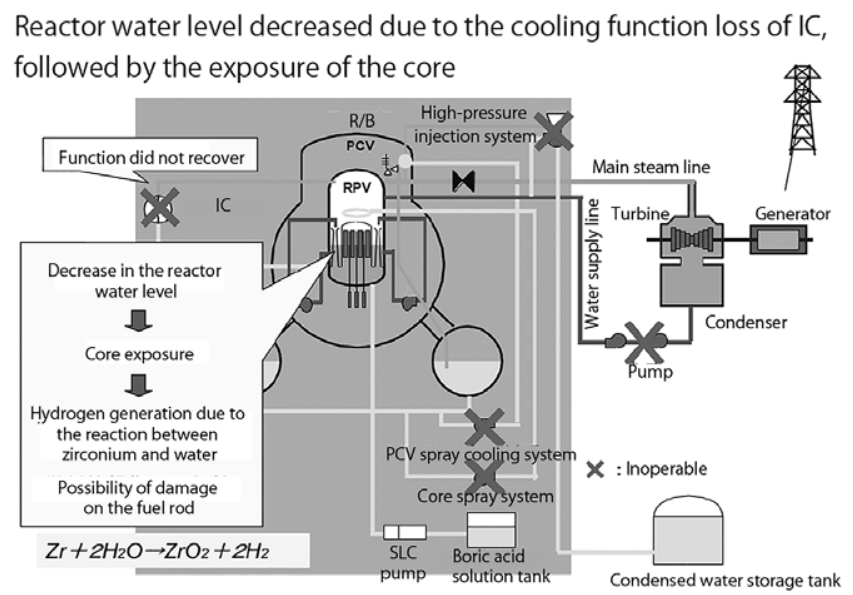

(b) Core exposure and hydrogen generation after IC stopped working

Figure 10 Loss of core cooling function and exposure of the core at Unit $1^{1)}$

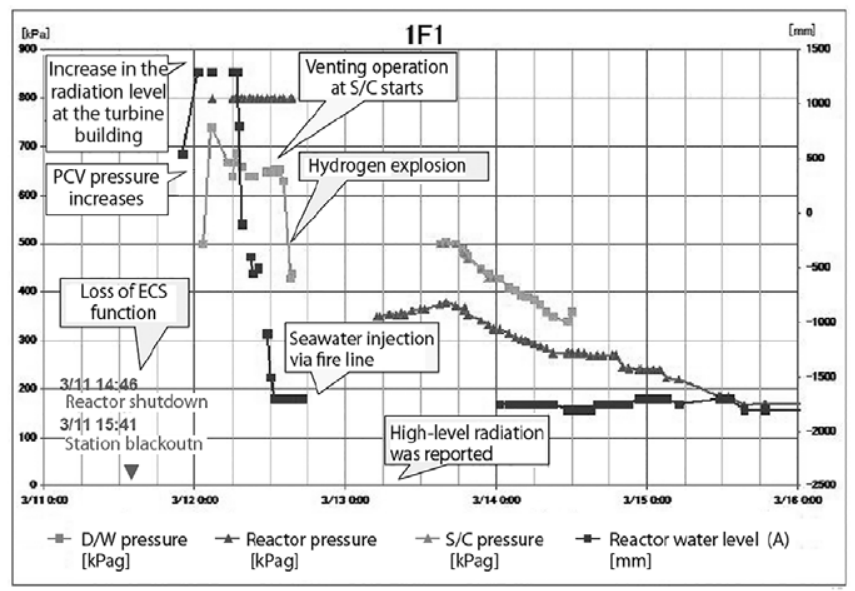

Figure 11 Time transition of the key parameters after the earthquake at Fukushima Daiichi Unit $1^{3)}$ 
12 (Figure 11). At 6:00, the PCV pressure decreased to $650 \mathrm{kPa}$. This means the leakage of vapor mixed with fission products (FPs) through top flange of PCV started. Indeed, the radiation level in the power station site started to increase, as shown in Figure 12. Moreover, the hydrogen from the zirconium water reaction was mixed in the steam. The hydrogen rose to the top floor in the $\mathrm{R} / \mathrm{B}$, where the shield plug, at the center of the operation floor, leaks the hydrogen through the gap around the circumference of the shield plug (about $20 \mathrm{~mm}$ ), and started to accumulate in the operation floor.

Meanwhile, at Unit 1, the severe accident mitigation measures stipulated in accident management (AM) were conducted (Figure 13). Water injection to core using mobile power generator and fire pump was conducted. First, fresh water injection was conducted using a CS system line connected to the firefighting system line and water from the firefighting tank while removing the vast amount of debris brought by the tsunami. At this point, it was necessary to conduct depressurization of RPV through the SRV used for the automatic depressurization system (ADS) because the discharge pressure of the fire pump, which was approximately $1 \mathrm{MPa}$, was not enough to inject water into the RPV of $7 \mathrm{MPa}$. Due to the station

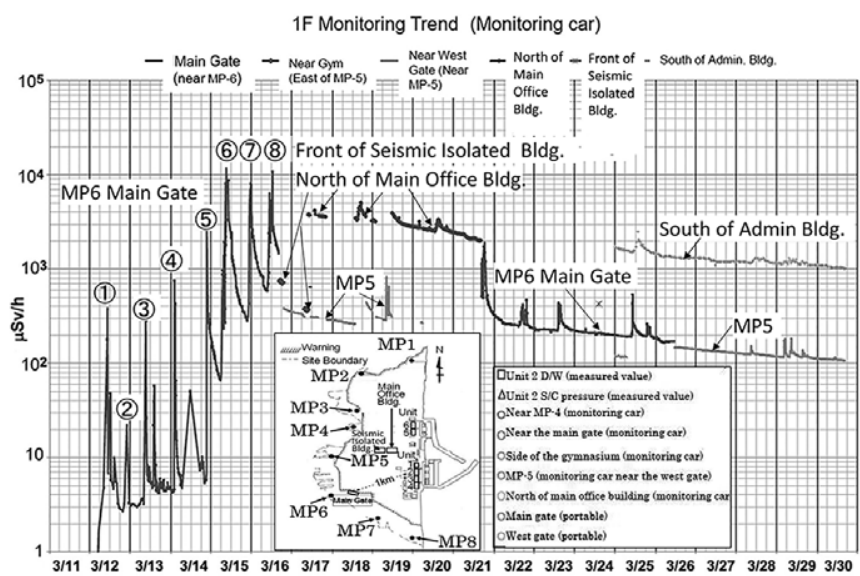

Figure 12 Radiation dose in the air dose rate in the Fukushima Daiichi NPS site ${ }^{2)}$

Seawater injection using Fire Pump

Venting was conducted via suppression chamber to reduce $\mathrm{PCV}$ pressure

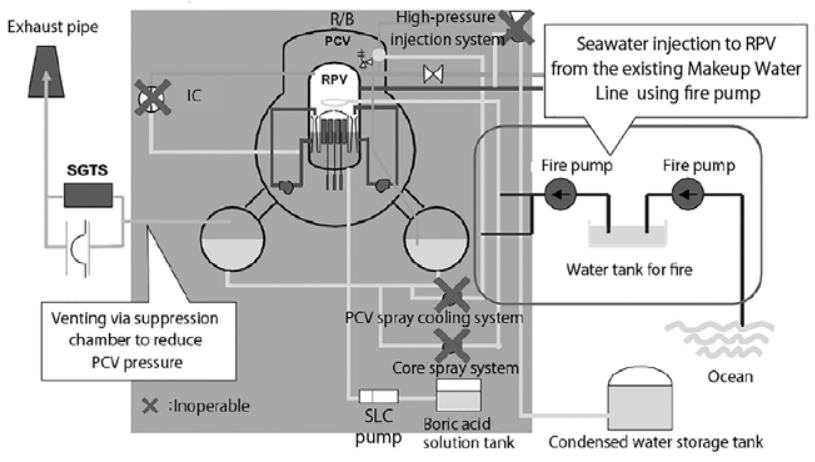

Figure 13 Severe accident mitigation measures at Unit $1^{1)}$ 
blackout, the elevator and lighting in the R/B, as well as the control panel in the main control room, were not working. Under such a situation, the batteries were brought in and connected to the solenoid valves attached to the SRV body to supply nitrogen gas to the actuator of the SRV and lift the valve shaft to open. After this operation, the reactor pressure decreased to $800 \mathrm{kPa}$ and water level was recovered to $1,300 \mathrm{~mm}$ after the injection of fresh water. However, the source of the freshwater ran out and the reactor water level significantly decreased to $-1,700 \mathrm{~mm}$, which is the level at which the fuel top became exposed (TAF standard). At 10:17 on March 12, venting operations such as manually opening the electric valve while the dose inside the building was already rising were conducted, and the PCV pressure started to decrease after 14:30. At this moment, the radiation dose level inside the NPS site (main gate) shown in Figure 12 rapidly increased to the peak of (1), that is, $400 \mu \mathrm{Sv} / \mathrm{h}$, and at $15: 36$, the hydrogen explosion that blew up the concrete wall above the operation floor of Unit 1 occurred during the live broadcasting by the media. AM stipulates that when freshwater is not available, seawater should be injected.

The seawater hose was manually installed down to the beach by going through the debris brought by the tsunami, which attached radioactive materials. It was considered as a difficult task, considering the emergency evacuation after the hydrogen explosion, among other things. In any case, following order from the Prime Minister's office, seawater injection using the CS line connected the fire pump started at 20:20. Following this seawater injection, steam was generated from the partially melted core and the radiation dose in the air increased again, as shown in Figure 12(2).

From the radiation ratio of $\gamma$-ray between the drywell and the wet well obtained from the $\gamma$-ray monitor installed inside PCV, called CAMS, at the morning of March 14, the core melting rate was estimated to be approximately $70 \%$. The time transition of the accident during the short period until the morning of March 14 is summarized in Table 1. After this time, the flow rate of the CS continued to decrease to $2 \mathrm{t} / \mathrm{h}$ while seawater injection continued, and from March 25, the pipe from Sakashita Dam was recovered and freshwater injection started, enabling switch from the fire-extinguishing line to the feedwater supply line. On March 29, the newly installed temporary external power cable from the transmission line from Tohoku Electric Power was connected and the water injection was switched to that using electric pumps. After the flow rate was increased to about $6 \mathrm{t} / \mathrm{h}$ and continued to inject water, the temperature of RPV and PCV that rose up to about $400^{\circ} \mathrm{C}$ started to decrease gradually. On April 7, nitrogen gas was injected into PCV because if the pressure inside PCV becomes negative and starts to suck in air, the hydrogen explosion can be prevented. Most of this outline is based on the published data by NISA and TEPCO, and addition/correction in response to the future investigation will be necessary for accuracy.

\section{(2) Unit 2}

As shown in Figure 14, at Unit 2, the steam turbine-driven RCIC continued its operation even after tsunami and water injection continued until around 11:00 on March 14. However, after RCIC stopped working, the water level in the reactor decreased rapidly. Seawater injection started at 16:34. However, they did not notice that the fuel of the firefighting pump was empty. During this time, the water level decreased to the bottom of active core (BAF) and fuel rod was completely exposed. When the seawater injection restarted again, high-temperature fuel rod reacted with water and significant amount of hydrogen mixed with stem was blown out into the S/P. At this time, the pressure in PCV started to increase rapidly due to steam and hydrogen. The dry vent was conducted before 24:00 on March 14 but it was failed by the loss of air of vent valve. This was accompanied by an increase in the radiation dose in 
Table 1 Accident progress of Unit 1 after the earthquake (short term)

\begin{tabular}{|c|c|c|c|c|}
\hline $\begin{array}{l}\text { Date } \\
\text { time }\end{array}$ & Reactor & $\begin{array}{c}\text { Primary containment vessel } \\
(\mathrm{PCV})\end{array}$ & Turbine building (T/B ) & 1F-1 NPS Site \\
\hline \multicolumn{5}{|l|}{$3 / 11$} \\
\hline \multirow[t]{2}{*}{$14: 46$} & Earthquake, Scram & & & \\
\hline & Loss of external power, IC & & HVAC Ventilation tripped & \\
\hline $15: 42$ & Station blackout, HPCI & & & \\
\hline \multirow[t]{2}{*}{$16: 36$} & Pressure control with SRV & & & \\
\hline & Reactor water level decrease & & & \\
\hline $17: 30$ & Core may have been exposed & & & \\
\hline $21: 30$ & $\begin{array}{l}\text { Decrease in reactor water } \\
\text { level drifted }(+450)\end{array}$ & & & \\
\hline 23:00 & & & High radiation level at $T / B$ & \\
\hline \multicolumn{5}{|l|}{$3 / 12$} \\
\hline \multirow[t]{2}{*}{$0: 30$} & $\begin{array}{l}\text { Reactor water level increased } \\
(+1,300)\end{array}$ & & & $\begin{array}{l}\text { Fire engine prepared for } \\
\text { water injection }\end{array}$ \\
\hline & $\begin{array}{l}\text { Depressurization with ADS } \\
\text { manually opened }\end{array}$ & & & \\
\hline $0: 49$ & & Abnormally high D/W & & \\
\hline $2: 30$ & Reactor pressure $0.8 \mathrm{MPa}$ & $840 \mathrm{kPa}$ (TEPCO data) & & \\
\hline 4:00 & & & & $\begin{array}{l}\text { Radiation level at the main } \\
\text { gate increased }\end{array}$ \\
\hline $6: 00$ & IC stopped (Disclosed by METI) & & & \\
\hline $6: 17$ & $\begin{array}{l}\text { Reactor water level started to } \\
\text { decrease again }\end{array}$ & & & \\
\hline $8: 30$ & $\begin{array}{l}\text { Reactor water level } 0 \text { (Top of } \\
\text { core) }\end{array}$ & & & Radiation level increased \\
\hline \multirow[t]{2}{*}{$10: 17$} & & Venting started (NISA data) & & at the main gate \\
\hline & & (Pressure did not drop) & & (around 10:00) \\
\hline \multirow[t]{2}{*}{$12: 35$} & $\begin{array}{l}\text { Water level indicate at JP inlet } \\
\text { (Drifted error) }\end{array}$ & & & \\
\hline & $\begin{array}{l}\text { After this point, the water level } \\
\text { at the core is unclear }\end{array}$ & & & \\
\hline \multirow[t]{2}{*}{$14: 30$} & & Venting (S/C-Stack) & & $\begin{array}{l}\text { High radiation level at site } \\
\text { boundary }\end{array}$ \\
\hline & & $(540 \mathrm{kPa}$ after $1 \mathrm{~h})$ & & \\
\hline \multirow[t]{2}{*}{$15: 36$} & & & $\begin{array}{l}\text { Hydrogen explosion at R/B } \\
\text { operation floor }\end{array}$ & \\
\hline & $\begin{array}{l}\text { Injection of seawater/boric acid } \\
\text { started (CS injection line) }\end{array}$ & & & $\begin{array}{l}\text { Radiation level increased } \\
\text { again at the main gate } \\
(\sim 20: 00 ?)\end{array}$ \\
\hline \multirow[t]{2}{*}{$20: 20$} & $\begin{array}{l}\text { After this point, no order to } \\
\text { recover the reactor water level }\end{array}$ & & & \\
\hline & $\begin{array}{l}\text { Reactor pressure: Stabilized } \\
\text { around } 0.36 \mathrm{MPa}\end{array}$ & Pressure unknown & & \\
\hline $3 / 13$ & No change & & & \\
\hline $15: 00$ & Reactor pressure: $0.451 \mathrm{MPa}$ & $\mathrm{D} / \mathrm{W}$ and $\mathrm{S} / \mathrm{C}$ at $600 \mathrm{kPa}$ & & \\
\hline $3 / 14$ & Melting rate $70 \%$ (CAMS) & & & \\
\hline \multirow[t]{2}{*}{$7: 00$} & & D/W: $162 \mathrm{~Sv} / \mathrm{h}$ & & \\
\hline & & S/C: $26.6 \mathrm{~Sv} / \mathrm{h}$ & & \\
\hline
\end{tabular}


the NPS site, which reached its peak 5 shown in Figure 12. On the next morning at 6:14, the pressure in PCV decreased at once to atmospheric pressure, together with the sound of explosion near the S/C was reported. At 9:00 on March 15, white steam appeared from the blowout panel and the radiation dose level reached the peak of $10,000 \mu \mathrm{Sv} / \mathrm{h}$ shown in Figure 126), and a large quantity of volatile FPs was released into the atmosphere.

\section{(3) Unit 3}

As shown in Figure 15, steam turbine-driven RCIC and HPIS continued to function at Unit 3 after the tsunami. However, possibly due to the issue with the freshwater source, water injection became no longer possible at 5:00 on March 13. During this time, the water level decreased to $-3000 \mathrm{~mm}$ but temporally recovered after the depressurization operation of ADS. By 13:00 on March 12, the pressure in the suppression chamber reached approximately $780 \mathrm{kPa}$. It is assumed that this caused deformation of the top flange of PCV, which in turn led to a leakage of steam, which includes hydrogen that accumulated in the upper part of R/B for about 2 days. At 11:01 on March 14, a violent hydrogen explosion accompanied by black smoke blew up the upper part of R/B and caused the deformation of the walls of the operation floor and the steel frames of the roof to the extent that the original shape was unrecognizable.

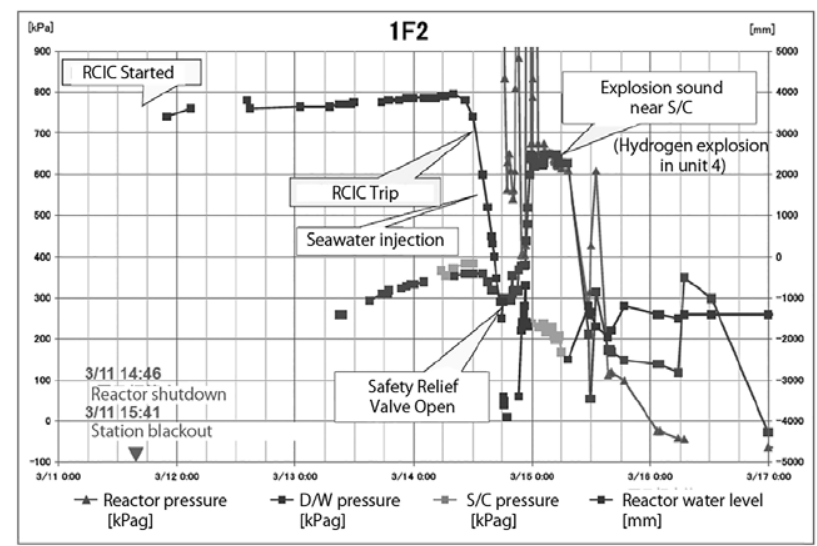

Figure 14 Time transition of Unit 2 after the accident ${ }^{1)}$

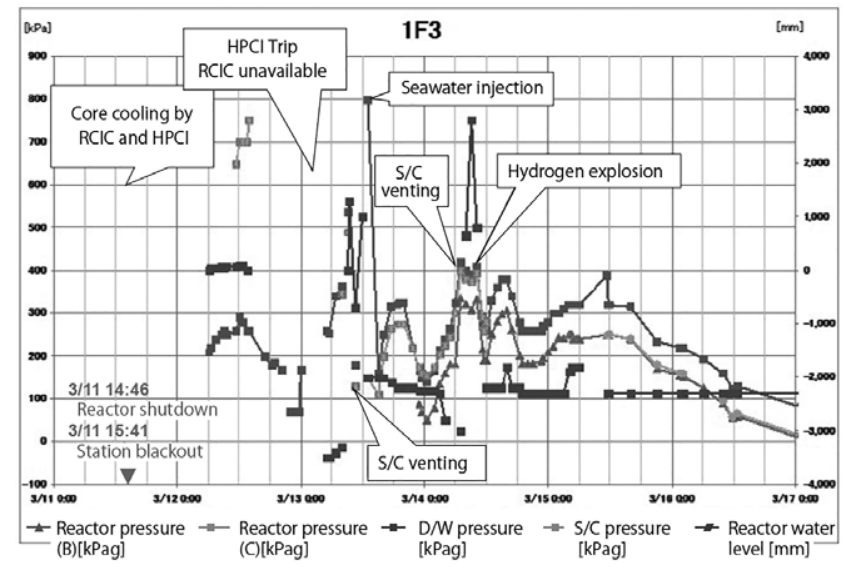

Figure 15 Time transition of Unit 3 after the accident ${ }^{1)}$ 
Table 2 Accident progress of Units 1-4 in Fukushima Daiichi NPS

\begin{tabular}{|c|c|c|c|c|}
\hline & Unit 1 & Unit 2 & Unit 3 & Unit 4 \\
\hline Output & $460 \mathrm{MW}$ & $784 \mathrm{MW}$ & $784 \mathrm{MW}$ & $784 \mathrm{MW}$ \\
\hline Start of its sales & March, 1971 & July, 1974 & March, 1976 & October, 1978 \\
\hline Manufacturer & GE & GE/Toshiba & Toshiba & Hitachi \\
\hline $\begin{array}{l}\text { Number of fuel rods } \\
\text { in the pool }\end{array}$ & Spent: 292, New: 100 & Spent: 587 , New: 28 & Spent: 514, New: 52 & Spent: 1331, New: 204 \\
\hline $\begin{array}{l}\text { When the fuel was } \\
\text { put in the pool }\end{array}$ & March 2010 & September 2010 & June 2010 & November 30, 2010 \\
\hline Damage of R/B & $\times$ Hydrogen explosion & $\triangle$ Blowout panel opened? & $\times$ Hydrogen explosion & $\times$ Hydrogen explosion? \& Fire \\
\hline $\begin{array}{l}\text { Emergency Diesel } \\
\text { Generator }\end{array}$ & $x$ & $x$ & $x$ & \\
\hline $\begin{array}{l}\text { Fuel rods in the } \\
\text { core }\end{array}$ & $70 \%$ damaged & $33 \%$ damaged & $\begin{array}{l}32 \text { MOX fuels were installed in the } \\
\text { core from September } \\
2010\end{array}$ & none \\
\hline Mar. 11 (Fri) & $\begin{array}{c}\text { 14:46 Scram by Earthquake } \\
\text { 15:41 Station blackout by } \\
\text { Tsunami, IC tripped }\end{array}$ & $\begin{array}{l}\text { 14:46 Scram by Earthquake } \\
\text { 15:41 Station blackout by } \\
\text { Tsunami, cooled by RCIC }\end{array}$ & $\begin{array}{l}\text { 14:46 Scram by Earthquake } \\
\text { 15:41 Station Blackout by } \\
\text { Tsunami, cooled by RCIC }\end{array}$ & $\begin{array}{l}\text { Under periodic inspection } \\
\text { 15:41 Station blackout by } \\
\text { Tsunami }\end{array}$ \\
\hline Mar. 12 (Sat) & $\begin{array}{l}\text { 15:36 Hydrogen explosion } \\
\text { Upper R/B was blown } \\
\text { off } \\
\text { 10:17 Wet venting } \\
\text { 20:20 Seawater injection }\end{array}$ & & & \\
\hline Mar. 13 (Sun) & & 11:00 Wet venting & $\begin{array}{l}\text { Cooling system stopped } \\
\text { 08:41 Wet venting } \\
\text { 13:00 Seawater injection }\end{array}$ & \\
\hline Mar. 14 (Mon) & & $\begin{array}{l}\text { 13:25 Cooling function lost } \\
\text { 16:34 Seawater injection } \\
\text { - Opening a hole on the } \\
\text { wall considered (not } \\
\text { carried out) } \\
\text { 18:22 } \\
\text { Total exposure of fuel rod } \\
\text { (pump fuel ran out but not } \\
\text { noticed) }\end{array}$ & $\begin{array}{l}\text { 05:17 Wet venting } \\
\text { 11:01 Hydrogen explosion }\end{array}$ & $\begin{array}{l}\text { 04:00 Water temperature of } \\
\text { spent fuel pool } 84^{\circ} \mathrm{C} \\
\text { (No data after this } \\
\text { time) }\end{array}$ \\
\hline Mar. 15 (Tue) & & $\begin{array}{l}\text { 00:02 Dry vent was tried (It was } \\
\text { failed by loss of air) } \\
\text { 06:14 Explosion sound near S/C } \\
\text { 12:00 PCV pressure decreased } \\
\text { to almost zero then went } \\
\text { up again up to } 300 \mathrm{kPa} \\
\end{array}$ & $\begin{array}{l}\text { 10:00 } 400 \mathrm{mSv} / \mathrm{h} \text { detected on the } \\
\text { mountain side }\end{array}$ & $\begin{array}{l}\text { 06:14 Hydrogen explosion? } \\
\text { 8m square two holes } \\
\text { on all sides (4th and } \\
\text { 5th floors) } \\
\text { 09:38 Smoke observed } \\
\text { 11:00 Fire extinguished }\end{array}$ \\
\hline Mar. 16 (Wed) & & & $\begin{array}{l}\text { 08:30 White smoke observed } \\
\text { 10:40 Radiation level increased } \\
\text { rapidly, workers evacuated } \\
\text { 11:30 The information was false, } \\
\text { workers came back again } \\
(100 \mathrm{ft}, 250 \mathrm{mSv})\end{array}$ & $\begin{array}{l}\text { 05:45 Fire recured again } \\
\text { Fire splay abounded } \\
\text { by high radiation level, } \\
\text { the fire extinguished } \\
\text { Photograph was taken } \\
\text { from the sky by the } \\
\text { helicopter of Self } \\
\text { Defense Force } \\
\end{array}$ \\
\hline Mar. 17 (Thurs) & & $\begin{array}{l}\text { Preparation of external power } \\
\text { cable was completed } \\
\text { The work of next day planned } \\
\text { to be about } 10 \mathrm{~h}\end{array}$ & $\begin{array}{l}\text { 09:48 Water drained from Self } \\
\text { Defense Force helicopter } \\
\text { (7.5 t by } 4 \text { times) } \\
300 \mathrm{ft} 87.7 \mathrm{mSv} \\
1000 \mathrm{ft} 4.13 \mathrm{mSv} \\
\text { Spent fuel pool volume } \\
1365 \mathrm{~m}^{3} \\
(9.9 \mathrm{~m} \times 12.2 \mathrm{~m} \times 11.3 \mathrm{~m}) \\
\text { 19:05 Riot Police water truck failed to } \\
\text { drain water into spent fuel pool } \\
\text { 19:35 Water sprayed from } 5 \text { fire } \\
\text { engines of Self Defense Force, } \\
\text { about } 30 \mathrm{t}\end{array}$ & $\begin{array}{l}\text { 21:45 Video shown water in } \\
\text { the pool was released } \\
\text { to press }\end{array}$ \\
\hline Mar. 18 (Fri) & $\begin{array}{l}\text { Preparation for external power } \\
\text { cable scheduled to be supplied } \\
\text { power on next day } \\
\text { Puddle of contaminated water } \\
\text { was discovered in the turbine } \\
\text { building. } \\
\text { Dose level was not measured }\end{array}$ & $\begin{array}{l}\text { Preparation of external } \\
\text { power cable } \\
\text { 22:00 Backup power panel was } \\
\text { supplied electricity from } \\
\text { external transmission line } \\
\text { Electricity for unit } 2 \text { will } \\
\text { be supplied on next day } \\
\text { Seawater injection } \\
5601 / \mathrm{min} \\
\text { A hole on the building } \\
\text { wall planned to be drilled } \\
\text { to protect hydrogen fire } \\
\sim 10: 30500 \mathrm{mSv} / \mathrm{h} \text { was recorded } \\
\text { (discovered on March } 23 \text { ) }\end{array}$ & $\begin{array}{l}\text { 13:55 Water sprayed from } 6 \text { fire } \\
\text { engines of Self Defense Force, } \\
\text { about } 40 \mathrm{t} \\
\text { U.S. Army water truck sprayed } \\
\text { about } 4 \mathrm{t} \\
\text { 24:30 Hyper rescue team of the } \\
\text { Metropolitan Fire Department } \\
\text { starts spraying water } \\
\text { 25:10 } 120 \mathrm{t} \text { of water was sprayed } \\
\text { Seawater core injection } \\
\text { 250 l/min } \\
\text { External power cable will be }\end{array}$ & $\begin{array}{l}\text { Temporary backup power } \\
\text { panel was installed } \\
\text { External power cable will be } \\
\text { connected by March } 20 \text { th }\end{array}$ \\
\hline Mar. 19 (Sat) & $\begin{aligned} & \text { External power cable } \\
& \text { was connected via the } \\
& \text { power center of Unit } 2 \\
& \text { Radiation level at North } \\
& \text { of the main office } \\
& \text { 14:00 } 3443 \mu \mathrm{Sv} \\
& \text { 17:00 } 3078 \mu \mathrm{Sv} \\
& \text { 21:00 } 2906 \mu \mathrm{Sv}\end{aligned}$ & $\begin{array}{l}\text { External power cable was } \\
\text { connected to the power panel } \\
1.5 \mathrm{~km} \text { cable was installed } \\
\text { Core cooling system will be } \\
\text { supplied power from tomorrow }\end{array}$ & $\begin{array}{l}\text { Total water injection by } \\
\text { Metropolitan Fire Department } \\
\text { was about } 2400 \mathrm{t} \\
\text { Water injection planned to be } 7 \mathrm{~h} \\
\text { (include unmanned injection) } \\
\text { From 14:05 the 19th to 3:40 the 20th } \\
\text { 17:25 Osaka fire brigade departure }\end{array}$ & $\begin{array}{l}\text { Installing cable from MC } \\
\text { vehicle to the power panel }\end{array}$ \\
\hline
\end{tabular}


After this, the reactor pressure and drywell pressure varied in parallel in almost the same pressure curve. It is estimated that a drift occurred in the indicated value of the drywell pressure due to the impact of the hydrogen explosion. It is necessary to examine these measurement instruments to obtain the accuracy of the event analysis.

\section{(4) Unit 4}

As the exchange work of shroud in conjunction with a periodic inspection was undergoing, all 1331 spent fuels and new 204 fuels, which were planned to be installed, were inserted into the rack in the spent fuel pool. At 6:14 on March 15, hydrogen explosion occurred and blew up the earthquake-proof class A walls of the 3rd and 4th floors of R/B (reinforced concrete wall, $50 \mathrm{~cm}$ thick) as well as the concrete wall of the 5 th floor and roof. However, the yellow paint coating of the top flange of PCV and green paint coating of the fuel exchanger were not burned. Thus, it is assumed that a detonation where a shock wave passes through in an extremely short time occurred. After the accident, there was enough water in the spent fuel pool to cover the fuel, which is supposed to be in the state as shown in Figure 16. However, it has

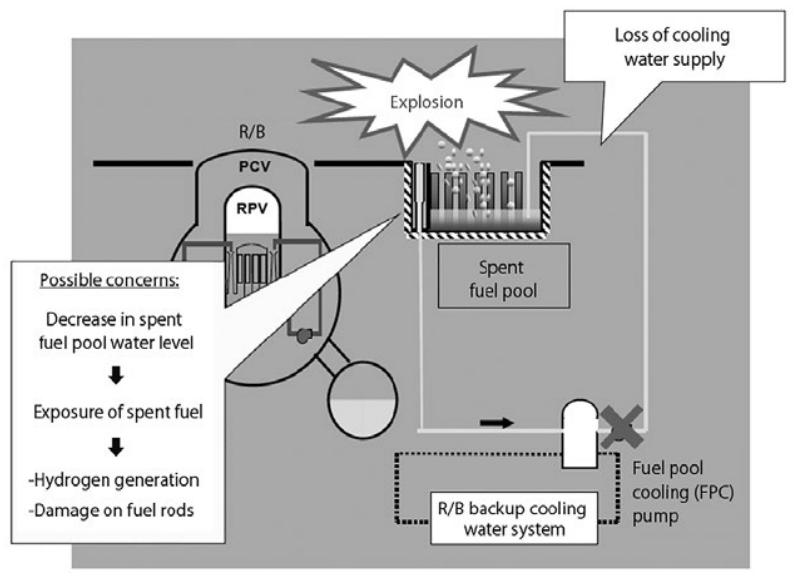

Figure 16 Concerns for spent fuel pool when external power source is lost ${ }^{1)}$

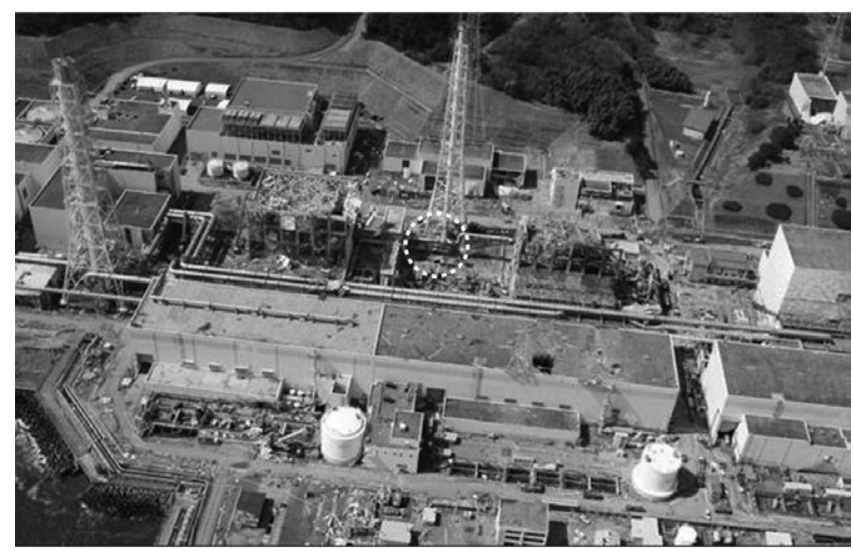

Figure 17 Damaged R/Bs of Units 4 and 3 and T-shape connected vent pipe at the lower end of stack.

(Photo: Air Photo Service) 
not been quantitatively explained. Since the reactor and equipment wells were filled with water, we assume that the partition panel between the spent fuel pool and reactor well came off due to an impact of the hydrogen explosion, which caused the water to flow from the reactor well to spent fuel pool. However, examination and verification are required to check whether the water in the spent fuel pool is sufficient to cool all the spent fuels after the earthquake.

\section{Lessons from the Three Mile Island Unit 2 Accident and Chernobyl Unit 4 Accident}

\section{Accident at Unit 2 of Three Mile Island NPS ${ }^{11)}$}

At the predawn on March 28, 1979, there was an accident at Unit 2 (power output 960 MW) of Three Mile Island NPS (TMI) located in Pennsylvania in the U.S., which caused a severe damage to the reactor core. The reactor of the TMI Nuclear Power Station was PWR (made by Babcock \& Wilcox). Its characteristics were small water volume in a steam generator (SG) and SG generate superheated steam. Following is its explanation with reference to Figure $18^{12)}$.

The accident occurred when the main feedwater pump, which supplied water from the condenser to SG, tripped. The axial feedwater pump immediately started automatically at a rated speed after $30 \mathrm{~s}$. However, the two discharge valves for the pump were closed; therefore, the water was not supplied to the SG. At this time, a sign plate that says "keep closed" was on the valve control switch in the control room. This should have been changed to "open" after the maintenance but they did not notice it during the patrol. It was already 8 min since the accident when an operator noticed it and opened the valves. At the reactor, the temperature and pressure of the primary system rose because water was not flowing to the SG, the pressure relief valve on the upper part of the pressurizer opened automatically, and the control rod was inserted to the core. The reactor shut down as it was designed to do so. However, the pressure relief valve did not close automatically; it was stuck open due to the damage on the pilot valve and could not be closed again, and caused the loss of coolant for the primary system and the pressure to become too low. This signal triggered the ECCS to start automatically, which started injecting the cooling water into reactor vessel. However, the operator stopped the valve of one system 4 min after the accident and after $10 \mathrm{~min}$, the valve of the other ECCSs

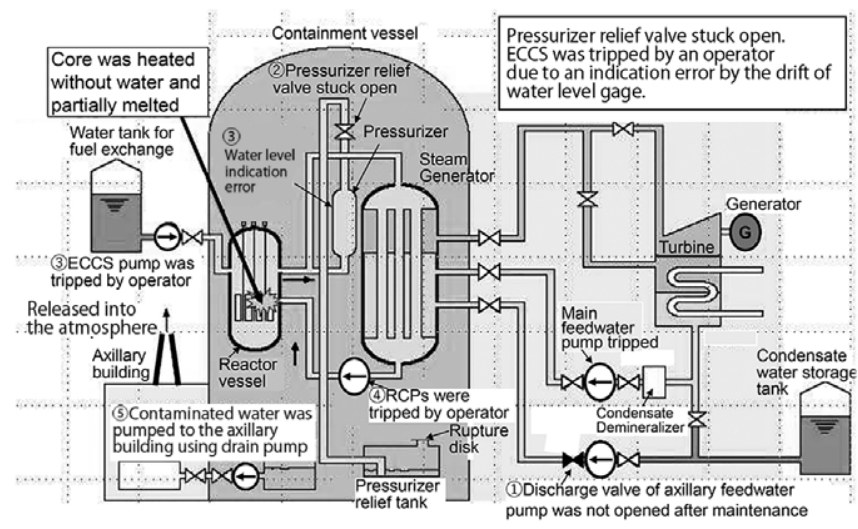

Figure 18 Accident at Unit 2 of Three Mile Island ${ }^{12)}$ in the U.S. 
of ECCS were also closed. This is because the drift in the water level in the pressurizer indicated full, and the operator was afraid that the pressure control would become difficult when the pressurizer was seemed to be full of water. However, after $12 \mathrm{~min}$, the operator was concerned about the fact that there was no cooling water route and he restarted ECCS. However, he was still concerned about the reactor vessel being full and pressure increasing, thus keeping the injection rate extremely low. Thus, leak flow rate was higher than that of injected into core and water level in the reactor decreased gradually. At the same time, the steam was blown down into the pressurizer relief tank in the containment vessel (CV) through the pressure relief valve that was kept stuck open. After some time, this tank became full and the water overflowed and started to accumulate in the sump at the bottom of CV. As the water level of this sump became too high, the radioactive water was sent to the auxiliary building by the drain pump. Furthermore, since there was a leakage path in the system, the FP gas that contains iodine 131 in the transferred water leaked into the building and was released to atmosphere through the ventilation system in the auxiliary building.

After the ECCS was restarted, the operator tripped the reactor coolant pump because it started to vibrate. As a result, the small amount of coolant circulation that somehow had managed to keep the core temperature in the state of remittance stopped. Due to this, the water in the core was evaporated and water level decreased, causing the fuel rod to be dry out and fuel rod to become heated. This led the fuel cladding tube start to damage. Then, the zircaloy of the cladding tube reacted with the steam under high temperature, oxidized, and generated a large amount of hydrogen. This hydrogen gas formed a large volume of non-condensable gas together with FP gas and started to accumulate in the upper part of the core.

Meanwhile, the fuel cladding became brittle due to the oxidization collapse and formed a large cavity on the central upper part of the core. The debris formed a thick pile in the bottom of the cavity and worsened the obstacle to the cooling; in addition, part of the heated fuel melted, flowed, and fell down to the bottom of the pressure vessel. Around this time, the operator finally noticed the leakage from the relieve valve and closed the stop valve and increased the flow rate of ECCS. This halted further progress of the core meltdown. However, the gas accumulated in the upper part of the pressure vessel prevented from the flow of coolant through the SG, which made the cooling of the primary system impossible, and then, the operation of ECCS for cooling continued. Thus, the stop valve connected with the relief valve was opened again to depressurize the primary system, and then closed again and started one of the primary cooling water pumps. This started circulation, and the thermometer at the hot and cold legs, which showed abnormal high temperature, returned to the normal temperature, while the cooling water started to flow through the core and the water that was heated in the core started being cooled by the SG. Thus, the stable cooling of the core was secured $16 \mathrm{~h}$ after the accident.

Though the accident itself was converged by the evening of March 28, an incorrect measurement which showed that a large amount of radioactive materials released from the stack was communicated to the U.S. Nuclear Regulatory Commission (NRC) on March 30, which triggered a discussion on various possibilities, leading the governor of Pennsylvania to issue an evacuation order for all pregnant women and pre-school age children within the 5 miles radius. As this was during a weekend, people followed one another in evacuation, and in the end, $40 \%$ of the residents within 10 miles radius evacuated outside the affected area. During this time, the streets were full of cars, while towns seemed like ghost towns. Regarding the exposure dose of the residents after this accident, the chairman of the Nuclear Safety Commission testified on the radiation level in the living environment at the Congress on April 4, saying that "even if one continues to stand on a point that is 0.6 miles from the power station, 
the exposure dose amount is maximum 80 mrem $(1 \mathrm{mrem}=0.01 \mathrm{mSv})$, in other words, equivalent to the dose of one or two times of X-ray examination of the chest." Moreover, the exposure dose amount of 2 million residents within $80 \mathrm{~km}$ radius around the power station is assessed to be on average $1.5 \mathrm{mrem}$, meaning that there was practically no exposure to the public.

The lesson of this accident can be learned from the social confusion and the psychological effect on the residents who were in panic. The report of the President's Special Investigation Commission created for this accident stated in the section on "Seriousness of the accident" that "according to our research on the health effect of the accident, our conclusion is that the impact of radioactive materials on a person's health was minute despite the significant damage on the power station because most of the radioactive materials were confined. The serious effect on the health of the accident was the psychological stress."

Immediately after this accident, NRC set up an accident research committee to examine its causes. Meanwhile, in response to the considerable social effect of the accident, President Carter created the President's Special Investigation Commission on April 11, two weeks after the accident, chaired by Dr. John G. Kemeny, the President of Dartmouth College. The commission consisted of 12 people including the state governor, specialists of various fields, and a representative of the local residents. They conducted a thorough investigation of not only the technical cause but also the background factors. This commission gathered public testimonies or conducted private interviews with over 150 people, and the materials they collected are said to reach $100 \mathrm{~m}$ when piled up.

This commission submitted its research result and improvement plan to the President, which stated that "based on the long years of experience in operating nuclear power stations, a mindset that nuclear power stations are perfectly safe was formed, which prevented from appropriate measures being taken in many aspects." In Japan, the Nuclear Safety Commission also suggested to immediately conduct a comprehensive review of each nuclear power station in the country, and that the Oi Nuclear Power Station currently in operation should stop its operation until it is verified that there is no concern about occurrence of such an accident. Moreover, the same commission established a special research commission to examine this lesson from various angles, and based on this examination, decided on the points to be reflected on future security measures that are categorized into "points related to design" and "points related to operation."

This most important lesson was not taken advantage of at the Fukushima Daiichi Nuclear Power Station. In other words, since it was based on an American layout design, the emergency $D / G$ was installed on the first floor of the basement of the turbine building without any protection against tsunami. Regarding this point, "Never Again," 13) the statement written by 16 famous international specialists in nuclear safety regulation, stated that "all the power was lost after a historically massive earthquake and equally historical large tsunami. Low-probability phenomena occurred simultaneously in an impossible manner, and the Fukushima site did not have a sense of danger." It appeals that instead of being content only with satisfying the initial safety standard, it is necessary to possess the latest knowledge and maintain the sense of immediacy and tension, and continue/strengthen the security effort. In other words, it strongly admonishes the negligence coming from a fixed mindset.

Furthermore, it demands from the aspect of research and development, (1) research to deepen the knowledge on the behavior of a nuclear reactor when its core is damaged, (2) research on the relation between human and machine, or the man-machine interface, (3) research on the system to support the operator's work, and (4) development of robots that can work in place of humans during accidents, to be prioritized. We believe that the academic 
society should verify that how the results of these researches helped understanding and convergence of the progress of the accident, and what was missing.

\section{Accident at Unit 4 of Chernobyl Nuclear Power Station ${ }^{11)}$}

On April 26, 1986, a nuclear accident occurred at Unit 4 of Chernobyl Nuclear Power Station located at approximately $100 \mathrm{~km}$ from capital Kiev of today's Republic of Ukraine (at the time, a part of the Soviet Union). The accident occurred late night at 01:23 AM. The operator in the control room said that he had heard the second explosion 2-3 s after the first one. The first explosion is deemed to have occurred because the fuel melted; the melted uranium dioxide became micro particles and diffused in the pressure tube and caused steam explosion. Though there are various interpretations of the cause of the second explosion, the theory that it was caused by the generated hydrogen and carbon monoxide is considered most likely. As a result, a quarter of the core was released into outside the reactor, and R/B was severely damaged such that it could not retain its shape to serve its purpose.

As shown in Figure 19 ${ }^{12}$, this reactor was a light water-cooled graphite moderated reactor (RBMK-type) developed in the former Soviet Union. The reactor core consists of a large piece of graphite with many vertically placed thick pressure pipes (1700 pipes). The fuel assembly is inserted into each pipe. Cooling water is run through them to heat/boil it and generates steam. This steam is separated from water in a steam-water separator (steam drum), which is then collected and sent to the turbine. This reactor is a thermal neutron reactor, and therefore, requires a neutron moderator, for which graphite is used. The light water flowing around the fuel in the pressure pipes mostly plays the role of heat transportation. When a core is designed with the concept of "graphite for moderation, light water for cooling," as in this reactor, there is a possibility of positive feedback due to the void generated during low output, unlike the light-water reactor system with the concept of "light water for both moderation and cooling" that is used in the power generation in Japan.

To counter this issue, the magnitude of the output and percentage of increase were monitored by measurement devices and scram device that automatically inserts more than 200 control rods on receiving an abnormal signal was attached. The test plan was to produce electricity for the station itself using the mechanical rotational energy (inertia) of the turbine with $20 \%-30 \%$ output. However, the output decreased to $1 \%$ due to the xenon effect. Because of

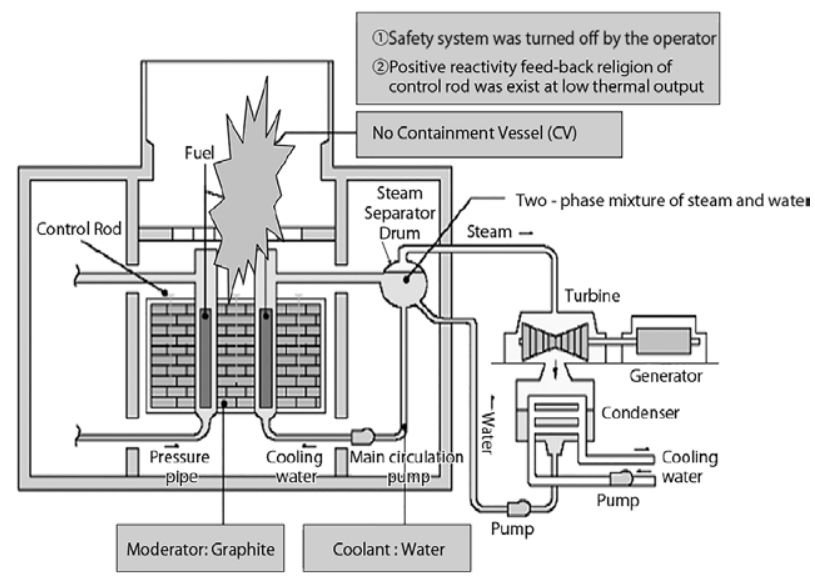

Figure 19 Factors of Chernobyl Nuclear Power Station Accident ${ }^{12)}$ 
this, despite the regulation (operation procedure) that forbade normal operation with less than $20 \%$ output, operators tried to recover the output by removing the safety device and pulling out many control rods. As a result, void was generated, accompanied by the reactor core instability at approximately $7 \%$ output, leading to the loss of control. As it has characteristic to temporally increase the output when the control rod is inserted in this situation, the nuclear fission energy reached $300 \mathrm{GW}$, which is about 100 times the rated output, in a few seconds after pressing the scram button, causing the nuclear runaway.

As discussed above, two explosions within a few seconds were followed by the nuclear runaway, steam explosion, and explosive burning of the hydrogen and carbon monoxide produced by the reaction between high-temperature graphite and water. This caused blowing up of radioactive materials reaching the stratosphere and then falling to a wide area from Ukraine to Europe. The radioactive contamination levels of Belarus, Ukraine, and Russia that surround the accident site were severe and caused much human damage. However, most of these people were the workers who were not informed about the danger of the accident and forced to respond to the emergency without protection clothes or masks or the children who ate vegetable or drank milk from the contaminated area. One can refer to the information from 237 people who responded to the emergency of the Chernobyl Accident and the exposure victims from Belarus, Ukraine, and Russia for a concrete proof of this.

To extinguish a large-scale graphite fire, the emergency response workers, including the firefighters, were forced to respond to the emergency without even protection masks and clothes. As a result, 28 people from the group of 93 who were exposed to 16-2.2 Gy radiation died within about 3 months (Table 3) ${ }^{14}$. For more than 20 people, the main causes of death were burn and respiratory disorder. In other words, because they were working without protection masks and clothes, the main cause of death was the burn inside and outside their bodies caused by the $\beta$-ray emitting nuclide coming into contact with skins or being inhaled. Moreover, all but one victims of an acute radiation syndrome suffered from myelopathy and most of the deceased suffered from intestinal damage. This accident was significantly different from that of the Fukushima Daiichi Nuclear Power Station not only in the amount of release of radioactive materials but also in the number of the dead and their cause of death.

According to the UNSCEAR 2000 report by the United Nations Scientific Committee on the Effects of Atomic Radiation ${ }^{14)}, 14$ years after the accident, no increase in leukemia among the exposure victims was observed, including the 245 who responded to the emergency, which appeared among the bomb victims of Hiroshima and Nagasaki in the early stage. It is estimated that in Hiroshima and Nagasaki, the functions of sensitive hematopoietic organs were damaged by an instantaneous strong radiation, and leukemia was caused by the later disorder. On the other hand, this result suggests that the human restorative/immune system works in the case of a long-term exposure to weak radiation, such as the case in the contaminated area

Table 3 Condition of emergency workers during the Chernobyl Accident ${ }^{14)}$

\begin{tabular}{|c|c|c|c|c|}
\hline $\begin{array}{c}\text { Degree of acute } \\
\text { radiation sickness }\end{array}$ & $\begin{array}{c}\text { Radiation Exposure } \\
\text { Dose (Gy) }\end{array}$ & $\begin{array}{c}\text { Number of people } \\
\text { hospitalized }\end{array}$ & Deceased & Number of survivors \\
\hline Light & $0.8-2.1$ & 41 & 0 & 41 \\
\hline Medium & $2.2-4.1$ & 50 & 1 & 49 \\
\hline Serious & $4.2-6.4$ & 22 & 7 & 15 \\
\hline Extremely serious & $6.5-16$ & 21 & 20 & 1 \\
\hline Total & & 134 & 28 & 106 \\
\hline
\end{tabular}

*Note: No acute radiation sickness was observed by other 103 emergency workers. 
of the Chernobyl Accident, and damage does not appear. Similarly, no increase in cancer has been observed in the disaster area. Naturally, it is necessary to monitor the future development but people who died of cancer after 10 years increased among the survivors of Hiroshima and Nagasaki, who were instantaneously exposed to more than $1 \mathrm{~Gy}$ radiation. This phenomenon is also supposed to be caused by the damage on the restorative/immune system and the accumulation of that damage along with aging. If the exposure level in a contaminated area is at a level that allows normal functioning of the human restorative/immune system, a meaningful increase in cancer might not be observed in the future, and requires a long-term research.

As the residents of the surrounding area were not aware of the Chernobyl Accident, there were many children in the large area contaminated by radioactive materials who ingested milk or vegetable and absorbed radioactive iodine into their bodies. Thus, 1800 cases of children with thyroid cancer have been reported at the time of UNSCEAR 2000 report $^{14}$, and the number continues to increase. Thyroid tumor caused by $\gamma$-ray exposure normally has more than 10 years of latent period but in the case of the Chernobyl Accident, it increased rapidly 5 years from the accident. Some specialists claim that the latent tumor originated from the chronic iodine shortage common in the interior of the continent contributed to this situation. This view considers that the thorough examination and its increased number after the accident contributed to the increase in the reported number of tumors. Meanwhile, Japanese people consume enough iodine, and during the Fukushima Daiichi Nuclear Station Accident, an early evacuation was conducted even though it was immediately after an earthquake, in addition to the preparation of the iodine neutralizer. Therefore, it is predicted that the health damage caused by radioactive iodine like the ones observed during the Chernobyl Accident will not appear.

Regarding radioactive cesium, no health damage has manifested in the residents themselves, including among those who refused to move to the area outside the forced emigration area with more than $550 \mathrm{kBq} / \mathrm{m}^{2}$, or who returned there. The reasons for this include the biological half-life of radioactive cesium, which can easily be discharged from the body, being about 100 days, the fact that radioactive cesium becomes equally distributed among muscles inside the body in the same behavior as potassium, including the radioactive potassium in human body, and the fact that it cannot have a concentrated effect on a specific important organ.

Figure 20 shows the possibility of radioactive materials leaking from the decrepit stone

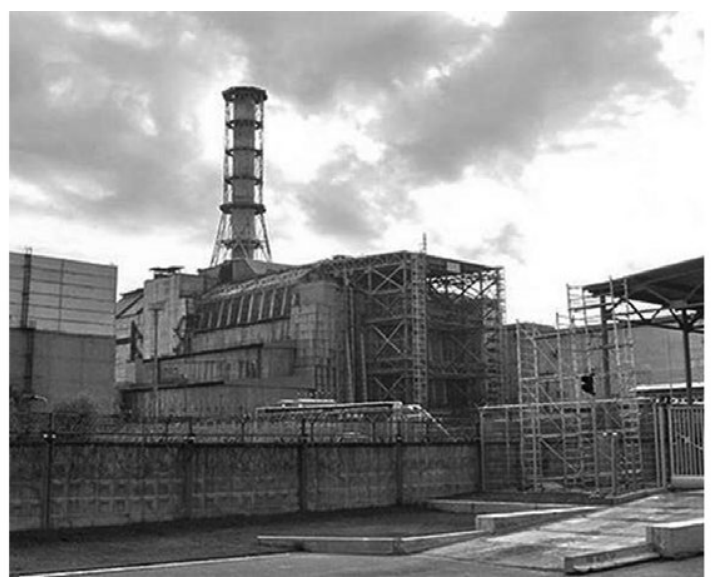

Figure 20 Chernobyl Nuclear Power Station after 25 years ${ }^{15)}$ 
coffin of Chernobyl Power Station after 25 years. However, the dose has been lowered to the point where sightseeing tour is possible. Based on the information of the contaminated areas within $400 \mathrm{~km}$ radius from the Chernobyl Power Station, Fukushima 25 years from now is predicted to have low contamination within $40 \mathrm{~km}$ radius. Moreover, we wish for a recovery to better future through measures such as soil exchange of schoolyards with high contamination level or active cultivation of plants that store radioactive cesium in their stalks or roots.

The health effect research result of the bomb victims from Hiroshima and Nagasaki whose exposure has already been 66 years ago are also precious data. A follow-up research on the mortality rate of a fixed group of 86,572 bomb survivors during 1950 was conducted in 1961 . This group was selected from the people who were within $10 \mathrm{~km}$ from ground zero of the atomic bombs; 8,500 people, $10 \%$ of the group, were exposed to $1-6 \mathrm{~Sv}$, and more than half of them were survivors from within $2.5 \mathrm{~km}$ from ground zero. In addition, 36,459 people assessed as with less than $5 \mathrm{mSv}$ exposure, who were deemed to practically have not been exposed, were selected as the comparison group to evaluate their difference from the group exposed to radiation.

According to the monitoring conducted until 1997, the number of people who died of cancer originating from the radiation exposure was 450 . It is predicted that when all 86,572 people are dead, the people who died of cancer originating from the exposure is predicted to be 800. Figure 21 shows the research result of the average age of death among the 86,572 atom bomb survivors. The data are the median value of the life expectancy of the survivor group whose exposure was up to $3 \mathrm{~Gy}^{16}$. Among the group exposed to $0.8 \mathrm{~Gy}$ or less radiation, while the person with shortest life displays dose dependency, among the people with median value or with the longest life, there is practically no difference with the group whose exposure was deemed zero. Though there are no data more detailed than this one, the following conclusion can be drawn. If the human body can withstand an instantaneous strong radiation, the human body function gradually recovers with time. However, the internal damage accumulated with age for people exposed to a high dose of radiation and the number of cases where they die of cancer originating through the so-called late effect increases. As a result, there was about 5-year difference between the median life expectancy of no exposure group and that of 3 Gy exposure group.

The Fukushima Daiichi Nuclear Power Station Accident did not cause an instantaneous high-dose exposure, as observed in Hiroshima and Nagasaki. Moreover, its exposure dose

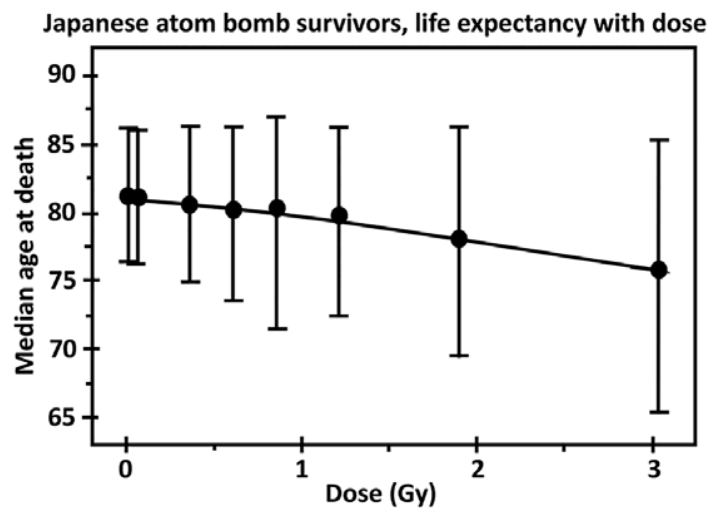

The data of the joint Japanese/US study show no significant difference among groups from 0 to $0.8 \mathrm{Gray}$ at median age of life span. No genetic Effects were caused by radiation in the children born to the survivors.

Figure 21 Average age of death among 86,572 atom bomb survivors ${ }^{16)}$ 
was sufficiently low in comparison with that in the Chernobyl Accident. Among the people from the area with a relatively high dose, such as the planned evacuation area of Fukushima Daiichi Nuclear Power Station or Iitate village, prevention of discrimination, prejudice, and reputational damage that psychologically tormented the survivors of Hiroshima and Nagasaki, and needless to say, the prevention of health damage by the radiation disorder are extremely important issues.

In recent years, the repair mechanism of DNA is starting to become clear. There is a special article on this subject published in Nihon Keizai Shimbun ${ }^{17)} .<$ p53 gene $>$ is the gene called "guardian of genome" that restrains cancer cells. When there is damage on DNA, it repairs the damage and prevents the cell from becoming cancerous by working on $<\mathrm{p} 21$ gene $>$, which multiplies the cells. With $<$ p53 gene $>$ becoming active, the multiplication of cancer cells is restrained. When single strand of a DNA is broken, its repair rate is $99.99 \%$, and when the double strand is cut into two, the rate is $90 \%$, and the cell that cannot be repaired disappears. It is considered that cancer appears when this function is impaired with aging, and future development of this research is expected. As seen in this example, based on the DNA-level restoration/cancer prevention mechanism that organisms acquire through evolution, it is reasonable to think that if it is appropriately managed, the number of residents/workers who develop cancer due to the effect of radiation from an accident will be significantly reduced.

\section{Mitigation Measures for Severe Accidents in Europe}

The most important lesson from Fukushima Daiichi Accident is that once a large-scale accident occurs, the financial burden including compensation, decontamination cost, removal cost of radioactive materials or buildings, and security against reputational damage, among others, is extremely large.

Numerous diverse equipment to prevent the expansion of an accident are designed and installed as backup on a light-water reactor in case it occurs. However, simultaneous occurrence of disadvantageous events triggered by, for instance, an equipment defect or a tsunami goes beyond the situations expected by the design, and as a result, leads to a major damage such as the core meltdown, as was the case of Three Mile Island Accident or the Fukushima Daiichi Nuclear Power Station Accident. Such a situation is called a "severe accident." The nuclear reactor PCV was highly effective as the last "fortress" during the Three Mile Island Accident. The accident at Chernobyl Power Station, which did not have PCV, released radioactive material to all over the world.

However, at the Fukushima Daiichi Nuclear Power Station, leakage and breakage occurred due to an increase in the internal pressure. What was necessary before the major damage occurred due to an increase in pressure in PCV was measures such as preventing breakage by reducing the pressure by venting after removing radiation using a filter (filtered vent) ${ }^{18)}$ or a static cooling system that cools PCV with water or air in order to prevent excessive increase in pressure in PCV due to decay heat. The measures to prevent the expansion of a severe accident or actively mitigate its effect and prepare necessary methods for these measures are called AM.

At the below discussed Beznau Nuclear Power Station, which is located in Switzerland, 11 steps of the safety/reliability trustworthiness improvement plan, as shown in Table 4, were implemented after TMI 2 accident ${ }^{19)}$. Among these, the filtered containment venting system became the trump card for restarting nuclear power stations after the Chernobyl Accident in European countries. It is a venting system with a filter, as shown in Figure 22. An active usage of nuclear energy near residential areas is being promoted through the examination of 
Table 4 TMI-2 Safety and reliability improvement project after the accident ${ }^{19)}$

-New reactor pressure vessel relief system (Post TMI)

-Thermal $\mathrm{H}_{2}$-recomniners inside containment (Post TMI)

-Replacement of refueling water storage tanks

-Compact simulator

-Provision of a full-scope simulator located offsite in the USA

-Bunkered emergency heat removal system (NANO project)

-Seismic requalification of mechanical/electrical equipment

-Filtered containment venting system (SIDRENT project)

-Analysis for pressurized thermal shock of RPV

-Separation of station load transformer area

-Additional emergency feed water system (ERGES project)

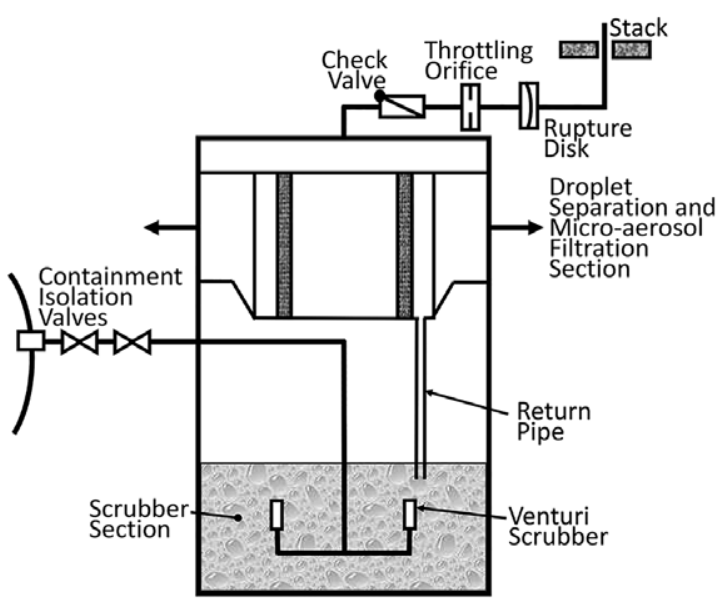

Figure 22 Filtered venting system ${ }^{18)}$

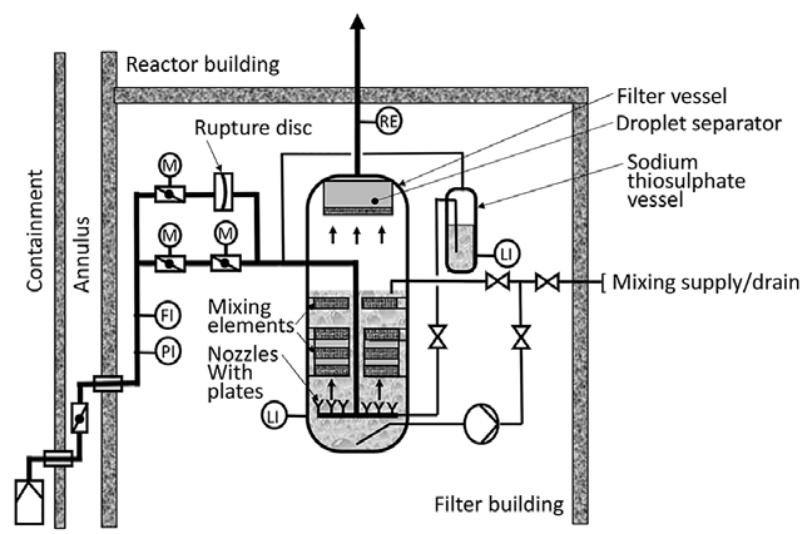

Figure 23 Venting system with filter in Switzerland ${ }^{19)}$ 
these measures and agreement with the population of a country of national referendums. Figure 23 shows the system diagram of the filtered venting facility of this power station. When a severe accident occurs, it starts this device with a highly efficient radioactive material removal function, which works without electricity before the pressure in PCV exceeds the designed pressure. If it is possible to release radioactive materials at a level that does not require evacuation, it is possible to both maintain the RPV and PCV integrity and prevent the health damage to the local residents and environmental damage without an evacuation. Even when there is an accident, there will be no trouble to the surrounding area. This should be the goal for the ultimate safety design of nuclear power stations.

Figure 24 shows Beznau Power Station and the surrounding residential area in Switzerland $^{20)}$. It is equipped with 2365 MWe reactors. This power station also engages with local nuclear power heat supply service shown in Figure $\mathbf{2 5}^{21}$. About 20,000 people living within $5 \mathrm{~km}$ radius from the power station, which is smaller than the emergency evacuation area in

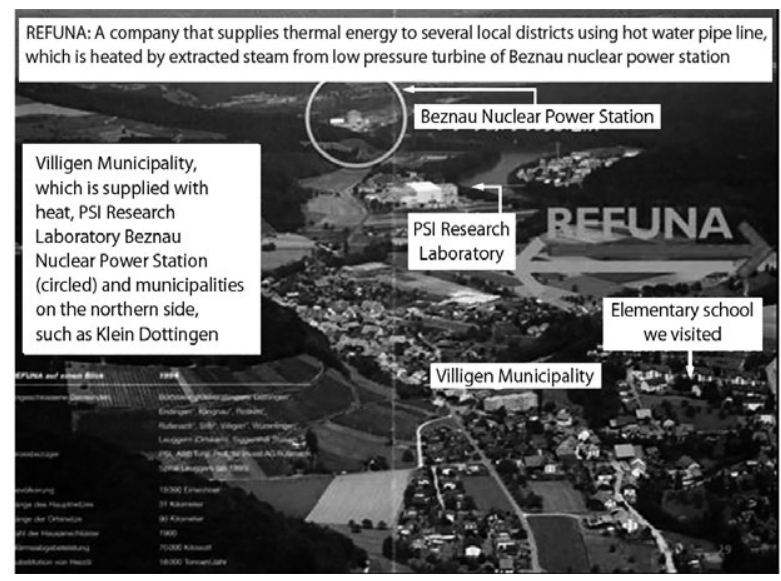

Figure 24 Regional symbiosis of Beznau Power Station in Switzerland ${ }^{20,21)}$

Districts Heat Supply Main Pipeline Network: Private homes, public facilities, commercial facilities, factories, research laboratories, and greenhouses for farming.

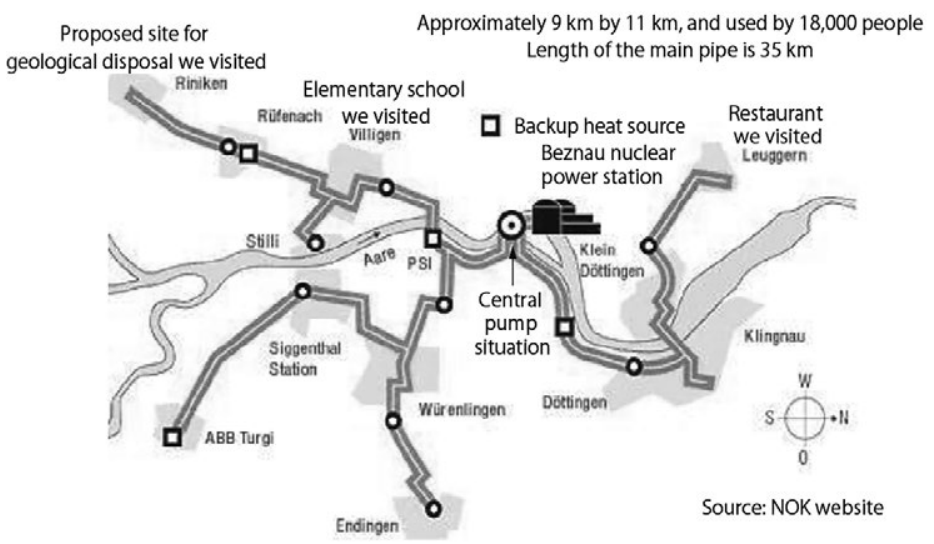

Figure 25 Local heat supply from Beznau Power Station ${ }^{20)}$ 
Japan, uses this system for the heating in winter and hot water throughout the year. $80 \%$ of the subscribers are private homes. With the economic stimulation of the area in view, public facilities such as schools and the like, commercial facilities, research laboratories, factory, and agricultural facilities (large-scale green house) are also actively using this service. The people of Switzerland, who maintains its neutrality since 1815 and was not involved in the First or Second World War and stayed peaceful, selected nuclear energy after discussing the measures and mental preparation for severe accidents and taking the energy security and environmental/carbon dioxide reduction measures into consideration.

\section{Provisional INES Level 7 Assessment}

The Nuclear and Industrial Safety Agency raised the assessment of the Fukushima Daiichi Accident to level 7 of International Nuclear Event Scale (INES), which is the most significant level. During the Chernobyl Accident, the reactor was destroyed by the explosion and a largescale graphite fire occurred, which led a large quantity of radioactive materials, including $3 \%-4 \%$ uranium in addition to iodine and cesium, to be spread across a wide area including European countries. Volatile nuclides, such as iodine and cesium, released from Fukushima were about $1 / 10$ of the Chernobyl Accident, and when it is evaluated with all the nuclides listed in INES, Fukushima, which did not release fuels such as uranium into the environment, released about $1 / 50$ of the Chernobyl Accident. Therefore, IAEA, which defined the standard of INES, objected the issuing of level 7 of INES. As per ROSATOM of Russia, level 7 assessed by the Nuclear and Industrial Safety Agency was excessive. Level 7 is for an accident that causes serious damage to the health of the local residents, which was not the case in Fukushima, where the exposure dose of the workers who were engaged in the recovery of the power station, was below the acceptable dose limit and did not cause health damage. From the extent of damage on the core, it was regarded that level 5 or level 6 was appropriate ${ }^{13)}$. Since it was assessed to be level 7, which was the same with Chernobyl, reputational damages such as the decrease in school trips and tourists in Aizuwakamatsu and sharp decrease in foreign students in the surrounding municipalities, are reported.

\section{Factor Analysis of the Fukushima Daiichi Power Station Accident and Future Measures}

\section{Accident Factor Analysis}

Although a detailed investigation is necessary in the future, when this accident is analyzed from the viewpoint of defense in depth based on the data published until this point, following are found to be the main factors of the accident.

(1) Loss of external power supplies for a long time: The nuclear and thermal power stations located on the large area of the eastern Japanese coast between Aomori Prefecture and Ibaraki Prefecture stopped due to the earthquake or the tsunami. In addition, the pylons in the premises of Fukushima Daiichi Power Station collapsed due to the earthquake. Therefore, recovery of external power took a long time, during which the batteries of the control panel or turbine-driven high-pressure water supply pump also ran out.

(2) Cooling systems that were dependent only on seawater failed together: Owing to the tsunami that went 4-5 $\mathrm{m}$ above the ground height of the premise, seawater entered the 
turbine building, flooded many electronic equipment and the emergency DG, and stopped them from functioning. In addition, the pump motor and other equipment of the seawater cooling system got flooded and failed.

(3) Occurrence of core cooling loss phenomenon: Due to the station blackout and breakdown of the IC or turbine-driven high-pressure injection pump, the injection cooling measures to the core were temporarily lost. This generated a large amount of hydrogen from the chemical reaction between the heated fuel cladding tubes and water. In addition, following the partial melting of the fuel pellet, the volatile components of nuclear FPs such as iodine and cesium were released in PCV, triggering a severe accident.

(4) Delay in the water injection to the core during severe accident countermeasures: Water should have been injected to the core promptly for severe AM (measures to mitigate severe accidents). Due to the delay in securing freshwater because freshwater in the premises ran out after long hours of injection and the pipe from the dam that was planned to be the water source was damaged, seawater was injected. However, because securing power supply vehicles and installing the hose to the fire-extinguishing pump while avoiding the debris from the tsunami took time, there were several hours of time loss to injecting water to the core.

(5) PCV overpressure and insufficient measures against hydrogen: Due to the venting conducted to prevent the internal pressure damage of PCV or the partial damage of PCV, iodine, cesium, and a large amount of hydrogen produced in (3) were released and caused hydrogen explosion. In addition, the emergency hydrogen processing system did not function due to the power loss.

(6) Cooling of the spent fuel pool: Water level could not be maintained at the spent fuel pool, and its fuel cladding tube might have been partially damaged.

\section{Basic Concept of Safety Measures}

As a nuclear reactor latently confines nuclear FPs in its reactor core, it is important to take multiple safety measures against external events such as earthquake or tsunami based on the following concept (defense in depth or multiple defense) : (1) Secure the cooling of the core. (2) Do not let an abnormality develop into an accident. (3) Even when there is an accident, keep its impact as small as possible.

If measures are to be taken for the abovementioned accident factors analysis from the perspective of defense in depth, it is necessary to plan the safety measures following the abovementioned concept of defense in depth. Specifically, following six points must be followed.

(1) Measures against loss of external power supplies for a long time: Strengthen the preparation for loss of external power supplies for a long time. Secure several power sources including hydropower and small-size thermal power. Take anti-earthquake/tsunami countermeasures for cabling, including the pylons in the premises.

(2) Prevent cooling systems that were dependent only on seawater from failing together: Install waterproof walls and doors to prevent seawater from entering the premises, important facilities for securing core cooling, and electric panel. In addition, prepare air-cooled emergency power source, power supply vehicles, and decay heat removal system as heat sink other than seawater.

(3) Prevent core cooling loss phenomenon: Prepare water injection with steam turbine-driven pump in order to prevent damage on fuel even when an important facility is damaged and power source or cooling function is lost. Attach a small generator to the steam turbine and make the butteries for control rechargeable. From the perspective of 
defense in depth, take measures for both piping rupture (LOCA) due to an earthquake and external power supplies/heat sink loss.

(4) Core water injection with speedy severe accident measures: Secure mobile power supply vehicles, partial permanent installation of cable connection to the emergency power source, maintenance of fire-extinguishing pump/water pump/fire hose, and conduct water injection training that follows the process of AM. Permanently install a part of water injection piping. Conduct trainings of water injection to the SG or the core, and extract and take measures against problems.

(5) Prevention of overpressure in PCV and measures against hydrogen: Strengthen the function to remove volatile iodine and cesium and take measures to prevent hydrogen explosion. We believe it is necessary to take medium- to long-term and fundamental safety measures such as employing the filtered vent used in Europe or a catalytic recombiner to install inside PCV.

(6) Cooling of spent fuel pool: Secure several water injection methods as well as mediumto long-term measures such as installation of air-cooling-type cooler or catalytic recombiner should be considered.

\section{Conclusions}

This accident at Fukushima Nuclear Power Station was an unprecedented event where severe phenomena occurred simultaneously at multiple units. Its situation was reported in detail by the mass media and many Japanese people experienced the devastation of the nuclear accident and the fear of radiation contamination. However, when the situation of each power station is analyzed with a calm mind, we can see a light of hope on the horizon. The Onagawa Nuclear Power Station, whose premises is located $14.8 \mathrm{~m}$ above sea level, managed to keep the damage of tsunami to minimal even though the town of Onagawa was heavily damaged by the same tsunami and achieved cold shutdown. A tsunami is an invasion of seawater, and we believe it is possible to physically stop it. Also, at the Fukushima Daini site, an emergency DG was installed in the R/B, and by changing the flooded seawater pump motor, cold shutdown was achieved.

During a severe accident, a filtered venting system that has a highly efficient radioactive material removal function that works without electricity is turned on before the pressure in $\mathrm{PCV}$ exceeds the design pressure. If radioactive materials can be released into the atmosphere at a level that does not require evacuation, it can both maintain the soundness of PCV and prevent health damage of the local residents and environmental damage without evacuation. How would this disaster have developed if such a facility had already been installed in Japan as the measures against external phenomena such as earthquake or tsunami? It is highly likely that the nuclear emergency could have remained minimal. From the perspective of defense in depth, the safety facility of nuclear power stations should be comprehensively reviewed with a strong will to not trouble the local resident near the power station no matter what disaster struck and even if the core is damaged. From the perspective of nuclear emergency mitigation/prevention, the Atomic Energy Society of Japan should urgently conduct various examinations for safety improvement with a strong will. With this reflection, we hope to regain the trust of local residents, develop world-class next-generation nuclear reactors, and the nuclear energy in Japan.

Finally, we would like to express our deepest gratitude to the people on ground who have 
been engaging in the recovery work of the nuclear power station since the immediate aftermath of the earthquake on March 11 during this unprecedented situation. Moreover, we offer our deepest condolences and goodwill as people who have been promoting the safety research of nuclear energy to the people who had to accept long-term evacuation and lost the foundation of life because of the tsunami and the nuclear power station accident. In the future, we will dedicate ourselves to the improvement in the safety of nuclear power stations, recovery of trust from the society, and the solutions to the future protection of the environment of this planet and securing energy for humanity.

We would like to acknowledge the suggestions from Takahisa Masuda, Yoshio Sunami, Yoshimori Hayashi, Yasuo Masuda, Masayoshi Kawai, Yasuhiko Fujii, Nobuaki Sato, Akira Kaneuji, and other members of the Fukushima recovery team F by the volunteers of a senior network of the Atomic Energy Society of Japan, which was published on March $28^{22}$. Moreover, Yasumasa Matsui of the nuclear power station team of TV Asahi supplied us with the time course of the media coverage of Fukushima Daiichi Nuclear Power Station, and Air Photo Service Co., Ltd. granted us permission to use their high-resolution aerial photos. We would like to express our gratitude to them here.

\section{References}

1) NISA, JNES. 2011 Earthquake off the Pacific Coast of Tohoku and the Earthquake Damage on Nuclear Power Station 2011 April. [in Japanese]

2) NISA, JNES. The 2011 off the Pacific coast of Tohoku Pacific Earthquake and the seismic damage to the NPPs.

3) Tokyo Electric Power Company. On the Impact of Nuclear Power Stations during 2011 Tohoku Earthquake and Their Current Situation, The Impact of Nuclear Power Stations during 2011 Tohoku Earthquake and Their Current Situation. 2011 April. [in Japanese]

4) Tokyo Electric Power Company. The Impact of Nuclear Power Stations during 2011 Tohoku Earthquake and Their Current Situation. 2011 April. [in Japanese]

5) Sakashita Dam: http://metalwings05.fc2web.com/dam/07_fukushima/sakashita/index.html [in Japanese]

6) Oka Y. TEPCO's Nuclear Power Plants suffered from big earthquake of March 11. 2011 March

7) Tokyo Electric Power Company. Issues to be reflected on the earthquake-proof safety evaluation following Unit 3 of Fukushima Daiichi nuclear power station and 2007 Niigata Prefecture Chuetsu offshore earthquake. 2010.June. [in Japanese]

8) Tokyo Electric Power Company. Earthquake-proof safety evaluation of Fukushima Daiichi power station Unit 3, buildings, structures and equipment important for safety and piping system. $2010 \mathrm{July}$. [in Japanese]

9) Kobayashi T, Yamaguchi K, Shimizu Y. Construction of Fukushima Daiichi Nuclear Power Station Unit 3 by Tokyo Electric Power Company Inc. Toshiba Rev. 1976; 31(12). [in Japanese]

10) Ichiki T. Layout plan of BWR power station. Toshiba Rev. 1969; 24(1). [in Japanese]

11) Ed. Atomic Energy Society of Japan. Century Opened by Nuclear Energy. 2004. [in Japanese]

12) Japan Atomic Energy Relations Organization. Collected Diagrams of Nuclear Power and Energy. 2011. [in Japanese]

13) Newspaper of Japan Atomic Industrial Forum. 2011 April; 2571th issue. [in Japanese]

14) United Nations Scientific Committee on the Effects of Atomic Radiation, UNSCEAR 2000 Report to the General Assembly with Scientific Annexes, Vol.II : Effects, http://www.unscear.org/unscear/ publications/2000_2.html

15) Wikipedia: http://ja.wikipedia.org/wiki/Chernobyl Accident, 2011. [in Japanese]

16) Lawson D. Engineering Disasters-Lesson to be learned.: ASME Press, New York; 2005.

17) Nihon Keizai Shimbun Prevent iPS Cell Turning into Cancer. Special article on iPS cell, Morning paper, 2009.9.20. [in Japanese]

18) Gavrilas $\mathrm{M}$ et al. Safety features of operating light water reactors of western design. CNES. 2000.

19) NOK AG. Beznau NPP Information Package. 2006 Edition.

20) REFUNA AG. REFUNA Pamphlet 1994 Edition. [in Japanese]

21) Sugiyama K. et al. Local nuclear energy heat supply, achievements in Switzerland. Nihon- 
Genshiryoku-Gakkai Shi (J. Atom. Energy Soc. of Jpn) 2006; 48(2). [in Japanese]

22) Narabayashi T. et al. Analysis and Proposal for Fukushima Daiichi Nuclear Power Plant Severe Accident-SNW Team F in AESJ, Genshiryoku Eye, Vol. 57, No. 6 , Nov. 2011, 10-13, [in Japanese]. https://iss.ndl.go.jp/books/R000000004-I11109113-00 